\title{
Safety, Infectivity, Immunogenicity, and In Vivo Stability of Two Attenuated Auxotrophic Mutant Strains of Salmonella typhi, 541Ty and 543Ty, as Live Oral Vaccines in Humans
}

Myron M. Levine," Deirdre Herrington," James R. Murphy, J. Glenn Morris," Genevieve Losonsky," Ben Tall," Alf A. Lindberg, "Stefan Svenson," Shahida Baqar," Mary Frances Edwards," and Bruce Stocker"

*Center for Vaccine Development, Division of Geographic Medicine, Department of Medicine, University of Maryland School of Medicine, Baltimore, Maryland 21201; ${ }^{\ddagger}$ Department of Clinical Bacteriology, Karolinska Institute, and ${ }^{8}$ Swedish National Bacteriology

Laboratory, Stockholm, Sweden; "Department of Medical Microbiology, Stanford University School of Medicine, Stanford, California 94305

\begin{abstract}
Two Salmonella typhi mutants, 541 Ty (Vi+) and 543Ty (Vi-), auxotrophic for $p$-aminobenzoate and adenine, were evaluated as live oral vaccines. 33 volunteers ingested single doses of $10^{\mathbf{8}}$, $10^{9}$, or $10^{10}$ vaccine organisms, while four others received two 2 $\times 10^{9}$ organism doses $4 \mathrm{~d}$ apart. No adverse reactions were observed. Vaccine was recovered from coprocultures of 29 of 37 vaccinees (78\%) and from duodenal string cultures of two; repeated blood cultures were negative. The humoral antibody response to $S$. typhi $\mathrm{O}, \mathrm{H}, \mathrm{Vi}$, and lysate antigens in serum and intestinal fluid was meager. In contrast, all vaccinees manifested cell-mediated immune responses. After vaccination, $69 \%$ of vaccinees overall and $89 \%$ of recipients of doses $\geq 10^{9}$ responded to $S$. typhi particulate or purified $O$ polysaccharide antigens in lymphocyte replication studies but not to antigens of other Salmonella or Escherichia coli. All individuals, postvaccination, demonstrated a significant plasma-dependent mononuclear cell inhibition of wild S. typhi.
\end{abstract}

\section{Introduction}

Typhoid fever remains an important public health problem in school age children and young adults in developing areas of the world and a health risk for travelers from industrialized countries who visit such areas (1). Heat-phenolized and acetone-dried killed whole cell Salmonella typhi parenteral vaccines have been shown to provide moderate to excellent efficacy in placebo-controlled field trials in endemic areas; in one study efficacy persisted for at least $7 \mathrm{yr}(2-7)$. However, these parenteral killed vaccines are unsatisfactory public health tools because of the frequency and severity of the adverse reactions that they evoke $(2,4,6)$. Approximately $25 \%$ of recipients develop fever, malaise, and notable local reactions; often the systemic reactions are severe and debilitating.

Ty21a, an attenuated $S$. typhi strain that lacks the Leloir pathway enzyme UDP galactose-4-epimerase (8), has shown the advantages of live oral vaccines (9-12). In field trials involving $\sim$ 16,000 vaccinated schoolchildren in Egypt (10) and 500,000 in Chile $(11,12)$, this live oral vaccine has provided moderate

Address reprint requests to Dr. Levine, Center for Vaccine Development, University of Maryland School of Medicine, 10 S. Pine Street, Baltimore, Md 21201.

Received for publication 24 July 1986.

\section{J. Clin. Invest.}

(C) The American Society for Clinical Investigation, Inc.

0021-9738/87/03/0888/15 \$1.00

Volume 79, March 1987, 888-902 to excellent protection while causing no notable adverse reactions. Despite these very encouraging results with Ty21a, there is room for further improvement. For example, Ty21a affords very little protection when given in only a single dose $(11,12)$. Furthermore, the method by which Ty2la was created, i.e., treatment of virulent $S$. typhi strain Ty21a with $N$-methyl- $N^{\prime}$ nitro- $N$-nitrosoguanidine (8), inadvertently gave rise to a vaccine strain with multiple genetic lesions beyond the enzyme activity alterations that were sought.

There is expectation that newer attenuated $S$. typhi mutants prepared by more precise genetic techniques may overcome the drawbacks of the Ty21a strain. Stocker and co-workers $(13,14)$ have developed two attenuated $S$. typhi strains that are being proposed as prototypes of the next generation of live oral typhoid vaccines. Vaccine strain 541Ty was derived from wild $S$. typhi strain CDC10-80 (phage type A) by transducing deletions in two separate genes, each previously characterized in S. typhimurium and affecting a different biosynthetic pathway (13-15). The deletion mutations of gene aro $A$ create a requirement for several aromatic compounds, including two, $p$-aminobenzoic acid and 2,3-dihydroxybenzoic acid, which are not mammalian metabolites (13-15). The second deletion mutation, at gene purA, causes a specific requirement for adenine (or an assimilable compound such as adenosine) (14-16). These nutritional requirements render $S$. typhi mutant 541Ty unable to maintain growth in mammalian tissues. A third mutation, of the his gene, leads to a histidine requirement. Although this last mutation does not affect virulence, it provides an additional biochemical marker to differentiate the vaccine strains clearly from wild $S$. typhi. Strain 543Ty is a spontaneously derived mutant of 541Ty that lacks the Vi polysaccharide capsular antigen; in all other ways this Vi-negative mutant is identical to 541Ty. The method of preparation of strains 541Ty and 543Ty and their genetic characteristics are described in detail elsewhere (14). This report summarizes the first clinical studies in man to assess the safety, infectivity, immunogenicity, and genetic stability in vivo of these oral typhoid vaccine strains.

\section{Methods}

\section{Volunteers}

Volunteers were 37 healthy young adults, 18-33 yr of age, from the metropolitan Baltimore community admitted to the isolation ward of the Center for Vaccine Development for a period of $18 \mathrm{~d}$. The study was explained in detail and witnessed; written consent was obtained. To ensure the informed nature of the consent procedure, volunteers were required to pass a written examination covering all aspects of the study including bacteriology, immunology, risks, benefits, and procedures.

The health of the participants before vaccination was assessed by 
medical history, physical examination, electrocardiogram, chest radiograph, psychological examination, and laboratory tests including complete blood count, blood chemistry analyses, liver function tests, and serologic tests for syphilis, hepatitis B surface antigen, and human immunodeficiency virus (HIV). Before vaccination, stool specimens were examined for bacterial enteropathogens, ova and parasites. After a 48-h period of acclimation on the ward, volunteers (4-10 per dose per vaccine strain) ingested the vaccine. Studies were carried out sequentially with increasing doses being given to three separate cohorts; results of completed studies with lower doses were reviewed before proceeding to a higher dose.

\section{Vaccine}

Stock cultures of $541 \mathrm{Ty}$ and $543 \mathrm{Ty}$ maintained at $-70^{\circ} \mathrm{C}$ in skim milk were thawed and plated onto sheep's blood agar supplemented with adenine $(10 \mu \mathrm{g} / \mathrm{ml})$, hypoxanthine $(1 \mu \mathrm{g} / \mathrm{ml})$, and 2,3 -dihydroxybenzoic acid $(1 \mu \mathrm{g} / \mathrm{ml}) 2 \mathrm{~d}$ before vaccination. After incubation at $37^{\circ} \mathrm{C}$ overnight, 20-30 typical colonies of the vaccine strains were picked, suspended in trypticase soy broth, and inoculated onto trypticase soy agar supplemented as above. After overnight incubation at $37^{\circ} \mathrm{C}$, the bacteria were harvested with $3 \mathrm{ml}$ of $0.85 \%$ saline and the concentration of bacteria was standardized turbidometrically. Dilutions of the suspensions were made in phosphate-buffered saline (PBS) to achieve the desired concentration of viable organisms per milliliter. The identity of the inoculum was confirmed by slide agglutination with $S$. typhi $\mathrm{O}, \mathrm{H}$, and $\mathrm{Vi}$ antisera. Replicate pour plate quantitative cultures were made of the inocula before and after vaccination to confirm the inoculum size.

\section{Oral vaccination}

$2 \mathrm{~g}$ of $\mathrm{NaHCO}_{3}$ were dissolved in $150 \mathrm{ml}$ of distilled water after which each volunteer drank $120 \mathrm{ml}$ in order to neutralize gastric acid and enhance survival of the vaccine organisms during passage through the stomach. 1 min later the vaccine inoculum suspended in the remaining $30 \mathrm{ml}$ of bicarbonate solution was ingested. Volunteers neither ate nor drank for $90 \mathrm{~min}$ before and after vaccination.

\section{Clinical surveillance}

Oral temperatures were taken every $2 \mathrm{~h}$ throughout the period of observation. All stools from every volunteer were collected in plastic "cholera seats" and examined, the consistency was graded on a five-point scale as previously described (17), and the volume measured if the stool was loose. Vaccinees were examined daily by the same physicians and interviewed for complaints of nausea, change in appetite, abdominal discomfort, headache, malaise, feverishness, or other symptoms. An oral temperature $\geq 37.8^{\circ} \mathrm{C}$ was considered fever, whereas diarrhea was defined as two or more loose stools within $48 \mathrm{~h}$ totalling at least $200 \mathrm{ml}$ in volume or a single loose stool $\geq 300 \mathrm{ml}$ in volume.

\section{Bacteriology}

Every stool passed by the volunteers was cultured to detect excretion of the vaccine strain or revertant $S$. typhi. Stool was inoculated into supplemented selenite $\mathrm{F}$ broth, incubated overnight at $37^{\circ} \mathrm{C}$ and subcultured onto supplemented Salmonella-Shigella (S-S) ${ }^{1}$ and xylose-lysine-desoxycholate agar. To quantitate shedding of the vaccine strain, $1 \mathrm{~g}$ of stool was serially diluted 10-fold in PBS and each dilution was plated onto S-S agar supplemented as above. Suspicious colonies were transferred to supplemented Kligler's triple sugar iron agar slants and confirmed by agglutination with $S$. typhi $\mathrm{O}, \mathrm{H}$ (and for $541 \mathrm{Ty}, \mathrm{Vi}$ ) antisera $(18,19)$.

Approximately 20 and $44 \mathrm{~h}$ after ingestion of vaccine, and in some instances also on the 6th and 11 th days after vaccination, fasting volunteers ingested gelatin-encapsulated string devices (Enterotest, HDC Corp., Mountain View, CA) to collect samples of bile-stained duodenal fluid (20). After $4 \mathrm{~h}$ the strings were removed, and the color and $\mathrm{pH}$ of the distal $15 \mathrm{~cm}$ on the string were recorded. By means of a gloved hand,

1. Abbreviations used in this paper: CFU, colony-forming unit; LPS, lipopolysaccharide; PHA, phytohemagglutinin; PWM, pokeweed mitogen; S-S, Salmonella-Shigella. duodenal fluid was tweezed from the distal portion of the string and cultured both qualitatively and quantitatively as above.

$5 \mathrm{ml}$ of blood were collected on days $2,4,6,8,10,12$, and 14 after vaccination and inoculated into $50 \mathrm{ml}$ of supplemented brain heart infusion broth containing $\mathbf{0 . 0 2 5 \%}$ sodium polyanetholsulfonate.

\section{Serology}

Sera were collected before and $11,15,22$, and $29 \mathrm{~d}$ after vaccination for measurement of antibodies to the $\mathrm{O}, \mathrm{H}$, and $\mathrm{Vi}$ antigens of $S$. typhi.

$O$ antibody. IgG antibody to purified $S$. typhi $\mathrm{O}$ antigen (Difco Laboratories, Detroit, MI) was measured by enzyme-linked immunosorbent assay (ELISA). $S$. typhi lipopolysaccharide $O$ antigen $(100 \mu \mathrm{l}, 10 \mu \mathrm{g} / \mathrm{ml})$ in carbonate coating buffer ( $\mathrm{pH}$ 9.6) (21) was applied to alternating wells of polystyrene microtiter plates (Dynatech Laboratories, Inc., Alexandria, VA) for $2 \mathrm{~h}$ at $37^{\circ} \mathrm{C}$ followed by $18 \mathrm{~h}$ at $4^{\circ} \mathrm{C}$. For each well containing antigen, a corresponding background control well without $O$ antigen was similarly treated. The wells were emptied and washed three times with PBS, pH 7.2, using a Titertek Microplate washer (Flow Laboratories, Inc., McLean, VA). Unbound plastic sites in the wells were blocked with $5 \%$ heat-inactivated fetal bovine serum in PBS for $1 \mathrm{~h}$ at $37^{\circ} \mathrm{C}$, after which the wells were washed three times with PBS containing $0.05 \%$ polyoxyethylene sorbitan monolaurate (Tween 20, J. T. Baker Chemical Co., Phillipsburg, NJ), hereafter referred to as washing buffer. Sera diluted 1:100 in PBS-Tween containing 1\% heat-inactivated fetal bovine serum were incubated in the wells for $1 \mathrm{~h}$ at $37^{\circ} \mathrm{C}$; the wells were then washed five times with washing buffer. Affinity column-purified (heavy chainspecific) goat anti-human IgG labeled with alkaline phosphatase (Kirkegaard \& Perry Laboratories, Inc., Gaithersburg, MD) was reacted in all wells for $1 \mathrm{~h}$ at $37^{\circ} \mathrm{C}$. (The specificity of the anti-IgG and anti-IgA conjugates was documented by reacting them in ELISA against chromatographically purified human IgG and IgA). After washing, as above, p-nitrophenyl phosphate in $10 \%$ diethanolamine buffer $(1 \mathrm{mg} / \mathrm{ml})$ (Kirkegaard \& Perry Laboratories, Inc.) was added for $30 \mathrm{~min}$ at $37^{\circ} \mathrm{C}$, and the reaction was stopped with $3 \mathrm{M} \mathrm{NaOH}$. Optical density was measured at $\mathbf{4 0 5} \mathrm{nm}$ with a Titertek Multiscan-MC reader. Net optical density was defined as the optical density of the antigen well minus the optical density of the corresponding background control well. Significant seroconversion was defined as an increase in net optical density of $\geq 0.15$. This degree of increase was statistically derived by testing paired sera from 30 Marylanders who received oral cholera or Escherichia coli vaccines and represents a value equal to the mean rise in net optical density of these paired sera plus 3 SD. The positive control serum used with each microtiter plate contains a high level of $\mathrm{O}$ antibody and represents a pool of high-titer sera from 12 healthy Chileans who manifested strong IgG $O$ antibody responses after immunization with $T y 21$ a vaccine.

IgM antibody to $O$ antigen in sera diluted 1:1,000 was measured in Stockholm by ELISA as previously described (22) using a swine antihuman IgM (heavy chain-specific) conjugate (Orion Diagnostics, Helsinki). A rise in net optical density of $\geq 0.40$ was calculated to be significant based on the mean rise plus $3 \mathrm{SD}$ of paired sera of the negative control population.

Intestinal secretory IgA antibody to $S$. typhi $\mathrm{O}$ antigen was also measured by ELISA. Before vaccination and 15 to $21 \mathrm{~d}$ thereafter, the vaccinees ingested polyvinyl chloride intestinal tubes as previously described to collect jejunal fluid (23). Immediately after collection the fluids were heated to $56^{\circ} \mathrm{C}$ for $30 \mathrm{~min}$ to inactivate proteolytic enzymes. The serum IgA content of the fluids was measured by radial immunodiffusion as previously described (23) and the fluids were lyophilized. Jejunal fluids were reconstituted to a concentration of $20 \mathrm{mg}$ IgA per $100 \mathrm{ml}$ of jejunal fluid, before testing for specific antibody by ELISA.

Alternating wells of microtiter plates were coated as above with $S$. typhi $\mathrm{O}$ antigen. Serial twofold dilutions of jejunal fluids in PBS, beginning at 1:4, were applied to the microtiter wells. The ELISA procedure was identical as described for the serum IgG assay except that alkaline phosphatase-conjugated goat anti-human IgA (heavy chain-specific, Kierkegaard \& Perry Laboratories, Inc.) was used. Fourfold rises in titer were considered significant.

$H$ antibody. $\mathrm{H}$ (flagellar) antibody was measured by the Widal tube 
Table I. Clinical Response of Healthy Adult Volunteers after Ingestion of Various Doses of Aro-, Pur- Auxotrophic Mutant Salmonella typhi Live Oral Vaccine Strains 541Ty or 543Ty

\begin{tabular}{lllll}
\hline & & \multicolumn{2}{l}{ No. of vaccinees with: } \\
\cline { 3 - 5 } Vaccine & $\begin{array}{l}\text { No. of } \\
\text { vaccinees }\end{array}$ & Diarthea & Fever* & $\begin{array}{l}\text { Abdominal } \\
\text { discomfort }\end{array}$ \\
\hline 541Ty & 23 & 0 & 0 & 0 \\
543Ty & 14 & 0 & 0 & 0 \\
\hline
\end{tabular}

* Oral temperature $237.8^{\circ} \mathrm{C}$.

agglutination test as previously described (24) using Salmonella virginia Like $S$. typhi, this serotype has the flagellar antigen d, but shares no somatic or capsular antigens with $S$. typhi (19).

$V i$ antibody. Vi antibody was measured by passive hemagglutination as previously described $(25,26)$ using sheep erythrocytes sensitized with highly purified Vi antigen prepared from Citrobacter freundii (kindly provided by Dr. John Robbins, National Institute of Child Health and Human Development, Bethesda, MD).

Antibody to $S$. typhi cell lysate. In order to detect antibody against possible uncharacterized protein antigens, an ELISA was also performed against a lysate of $S$. typhi. The lysate was prepared by treating log-phase organisms of strain 5077 with a Ribi cell fractionator (DuPont-Sorvall, Newtown, CT). Antigen ( $25 \mu \mathrm{g}$ in $100 \mu \mathrm{l}$ ) coated on microtiter plates as for the $\mathbf{O}$ antibody assay. Serial twofold dilutions of serum were tested, beginning with a dilution of 1:20. The ELISA was performed as for measurement of $O$ antibody in serum. Fourfold or greater rises were considered significant.

\section{Measurement of cell-mediated immunity}

Assays to detect the development of cell-mediated immunity after vaccination included measurement of the replication of lymphocytes in vitro in the presence of selected $S$. typhi and control antigens and assessment of the ability of mononuclear cells and plasma, alone and in combination, to inhibit the growth of $S$. typhi in vitro. These assays were carried out using blood specimens collected before, and 22 and 61-96 days after vaccination.

Lymphocyte replication assays. The lymphocyte replication assay employed mononuclear cells isolated from peripheral blood after FicollHypaque gradient centrifugation (lymphocyte separation medium, Litton Bionetics, Kensington, MD). These cells were cultured in microculture plates at an initial density of $1 \times 10^{5}$ cells per well in a total volume of $0.22 \mathrm{ml}$ of medium RPMI 1640 (M. A. Bioproducts, Walkersville, MD)

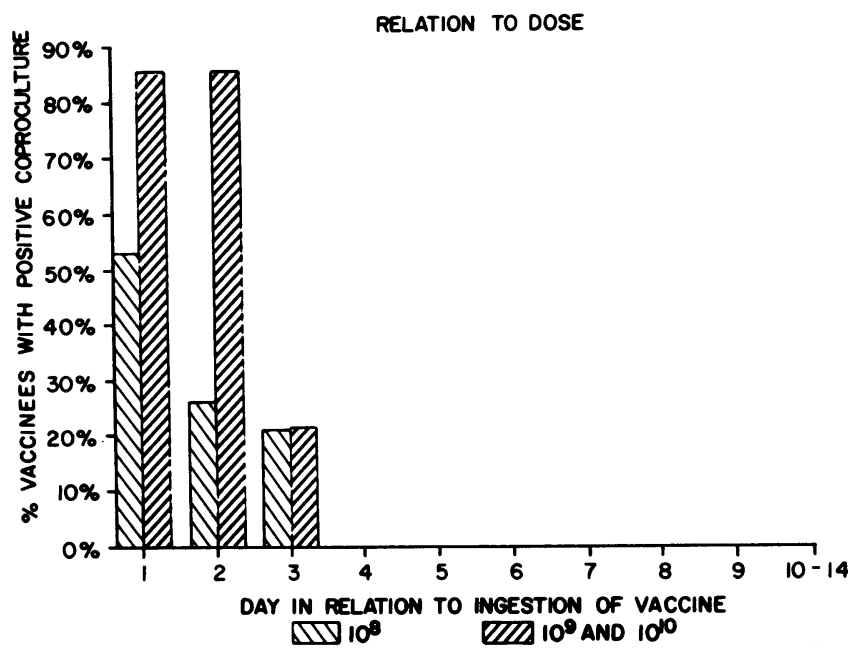

Figure 1. The prevalence and duration of excretion of 541Ty or 543Ty vaccine after ingestion of a single (or first) dose is shown for those who ingested doses of $10^{8}$ or $\geq 10^{9}$ vaccine organisms. The percentage of vaccinees with positive coprocultures on each day was notably higher in those who received larger ( $\geq 10^{9}$ organisms) doses of vaccine. No vaccine organisms were isolated beyond the third day after ingestion.

containing $10 \%$ pooled normal human serum, $2 \mathrm{mM}$ glutamine, and 50 $\mu \mathrm{g} / \mathrm{ml}$ gentamicin. In preparing the human serum pool, individual sera of prospective donors were evaluated to determine whether the sera were intrinsically suppressive to phytohemagglutinin (PHA) or pokeweed mitogen (PWM)-induced lymphocyte replication or whether the sera alone stimulated lymphocyte replication in the absence of mitogen or antigen. Sera that were mitogenic or suppressive to lymphocyte replication were discarded.

The mononuclear cells were cultured in medium alone or in medium containing mitogens or antigens. The mitogens, PHA (Difco Laboratories) and PWM (Gibco, Grand Island, NY), were used at $250 \mu \mathrm{g} /$ culture or at a final dilution of $1: 110$, respectively. Both inactivated whole bacteria (particulate antigen) and purified $O$ polysaccharides free of endotoxin $(27,28)$ were employed as antigens. The particulate $S$. typhi antigen consisted of heat-phenolized whole bacteria (Wyeth typhoid vaccine, Wyeth Laboratories, Marietta, PA); control particulate antigens, which were prepared in this laboratory by the same method of heat-phenol treatment, included S. enteriditis (SH1262), S. thompson (ATCC 8391, American Type Culture Collection, Rockville, MD), and E. coli strain HS (29). Briefly, to prepare particulate antigens, bacterial strains were

Table II. Isolation of S. Typhi Vaccine Strains 541Ty and 543Ty from Stool, Duodenal Fluid and Blood Cultures in Relation to Dose of Vaccine Ingested

\begin{tabular}{|c|c|c|c|c|c|c|}
\hline Vaccine & $\begin{array}{l}\text { Inoculum* } \\
\text { (no. of doses) }\end{array}$ & $\begin{array}{l}\text { No. of } \\
\text { vaccinees }\end{array}$ & $\begin{array}{l}\text { No. (\%) of } \\
\text { vaccinees } \\
\text { with positive } \\
\text { coprocultures }\end{array}$ & $\begin{array}{l}\text { Peak geometric }{ }^{\star} \text { mean } \\
\text { excretion (range) }\end{array}$ & $\begin{array}{l}\text { No. with positive } \\
\text { duodenal string } \\
\text { cultures }\end{array}$ & $\begin{array}{l}\text { No. with } \\
\text { positive blood } \\
\text { cultures }\end{array}$ \\
\hline \multirow[t]{4}{*}{ 541Ty } & $10^{8}(1)$ & 10 & $7(70)$ & $5 \times 10^{1}\left(10^{1}-5 \times 10^{3}\right)$ & 0 & 0 \\
\hline & $10^{9}(1)$ & 5 & $5(100)$ & $4 \times 10^{4}\left(10^{1}-2 \times 10^{5}\right)$ & 0 & 0 \\
\hline & $10^{9}(2)$ & 4 & $3(75)$ & $3 \times 10^{3}\left(10^{1}-9 \times 10^{5}\right)$ & 1 & 0 \\
\hline & $10^{10}(1)$ & 4 & $4(100)$ & $6 \times 10^{4}\left(10^{1}-5 \times 10^{6}\right)$ & 1 & 0 \\
\hline \multirow[t]{2}{*}{ 543Ty } & $10^{8}(1)$ & 9 & $5(56)$ & $3 \times 10^{1}\left(10^{1}-2 \times 10^{3}\right)$ & 0 & 0 \\
\hline & $10^{9}(1)$ & 5 & $5(100)$ & $10^{4}\left(10^{1}-6 \times 10^{5}\right)$ & 0 & 0 \\
\hline
\end{tabular}

\footnotetext{
* No. of viable organisms administered with $2.0 \mathrm{~g}$ of $\mathrm{NaHCO}_{3}$. ${ }^{\ddagger}$ No. $S$. typhi/gram of stool in persons with positive cultures. If only enrichment
} cultures were positive, a value of $10^{1}$ organisms/gram stool was assigned since the level of detection of direct plating is $\geq 10^{2}$ organisms/gram. 
grown on 6-in agar plates containing veal infusion agar. After overnight incubation at $37^{\circ} \mathrm{C}$, confluent growth was harvested from the agar surface using $10 \mathrm{ml}$ of PBS, pH 7.2, containing 0.5\% phenol (PBS-phenol), centrifuged, and washed twice in PBS-phenol, and resuspended in $10 \mathrm{ml}$ of PBS-phenol. The washed bacterial suspension was heated to $56^{\circ} \mathrm{C}$ in a water bath for $30 \mathrm{~min}$, washed two more times as above, resuspended in PBS-phenol to a concentration of $2 \times 10^{10}$ bacterial cells $/ \mathrm{ml}$ (quantitated by direct count in a Petroff-Hausser chamber), and stored at $4^{\circ} \mathrm{C}$.
Before use in lymphocyte replication assays, the heat-phenolized bacterial antigens were washed three times and resuspended in isotonic saline to a concentration of $5 \times 10^{7}$ bacterial cells $/ \mathrm{ml} ; 1 \times 10^{6}$ bacterial cells were used per culture.

The O polysaccharide antigens were prepared from $S$. typhi, $S$. enteriditis, $S$. thompson, and $S$. anatum as previously described $(27,28)$. Briefly, lipopolysaccharide (LPS) was extracted from the various Salmonella by the hot water-phenol method and then partially delipidated

Table III. Serologic Response of Volunteers after Oral Vaccination with Auxotrophic S. typhi Mutant Strains 541Ty or 543Ty

\begin{tabular}{|c|c|c|c|c|c|c|c|c|c|c|c|c|c|c|}
\hline \multirow[b]{3}{*}{ Vaccinee } & \multirow{2}{*}{\multicolumn{2}{|c|}{$\begin{array}{l}\text { Serum IgG O } \\
\text { antibody* }\end{array}$}} & \multirow{2}{*}{\multicolumn{2}{|c|}{$\begin{array}{l}\text { Serum IgM O } \\
\text { antibody }\end{array}$}} & \multirow{2}{*}{\multicolumn{2}{|c|}{ Serum $\mathrm{H}$ antibody" }} & \multirow{2}{*}{\multicolumn{2}{|c|}{$\begin{array}{l}\text { Serum Vi } \\
\text { antibody }\end{array}$}} & \multicolumn{4}{|c|}{ Serum antibody to $S$. typhi lysate } & \multicolumn{2}{|c|}{$\begin{array}{l}\text { Intestinal serum } \\
\text { IgA } O \text { antibody }\end{array}$} \\
\hline & & & & & & & & & \multicolumn{2}{|l|}{ IgG } & \multicolumn{2}{|l|}{ IgA' } & \multirow[b]{2}{*}{ Pre- } & \multirow[b]{2}{*}{ Peak } \\
\hline & Pre-ll & Peak' & Pre- & Peak & Pre- & Peak & Pre- & Peak & Pre- & Peak & Pre- & Peak & & \\
\hline \multicolumn{15}{|l|}{ Cohort I } \\
\hline $7001-1$ & 0.15 & 0.24 & 0.57 & 0.53 & $<20$ & $<20$ & 80 & 160 & 1,280 & 1,280 & 80 & 40 & $<4$ & 4 \\
\hline-2 & 0.02 & 0.03 & 0.66 & 0.86 & $<20$ & $<20$ & $<20$ & $<20$ & 640 & 320 & 20 & 40 & $\mathrm{NA}^{* *}$ & NA \\
\hline-3 & 0.14 & 0.14 & 0.14 & 0.40 & $<20$ & $<20$ & $<20$ & $<20$ & 5,120 & 5,120 & 80 & 80 & $<4$ & $<4$ \\
\hline-4 & 0.01 & 0.02 & 0.11 & 0.22 & $<20$ & $<20$ & $<20$ & $<20$ & 320 & 320 & 40 & 40 & NA & 4 \\
\hline-5 & 0.00 & 0.02 & 0.33 & 0.65 & $<20$ & $<20$ & $<20$ & $<20$ & 2,560 & 5,120 & 40 & $160^{\#}$ & $<4$ & $<4$ \\
\hline-6 & 0.09 & 0.03 & 0.28 & 0.33 & $<20$ & $<20$ & $<20$ & $<20$ & 1,280 & 1,280 & 80 & 160 & $<4$ & 4 \\
\hline-7 & 0.27 & 0.36 & 0.18 & 0.40 & $<20$ & $<20$ & $<20$ & $<20$ & 320 & $1,280^{\ddagger}$ & 320 & 160 & NA & 4 \\
\hline-8 & 0.06 & 0.10 & 0.44 & 0.50 & $<20$ & $40^{\ddagger}$ & $<20$ & $<20$ & 1,280 & $5,120^{\#}$ & 320 & 640 & NA & NA \\
\hline-9 & 0.52 & 0.44 & 1.82 & 2.19 & $<20$ & $<20$ & 40 & 80 & 2,560 & 5,120 & 160 & 320 & $<4$ & 4 \\
\hline-10 & 0.07 & 0.08 & 0.97 & 1.36 & 160 & 160 & $<20$ & $<20$ & 5,120 & 5,120 & 80 & $320 \#$ & 4 & 8 \\
\hline-11 & 0.13 & 0.13 & 0.21 & $0.84 \#$ & $<20$ & $<20$ & $<20$ & $<20$ & 640 & 1,280 & 640 & 320 & 8 & 8 \\
\hline-12 & 0.40 & $0.66^{\ddagger \pm}$ & 0.31 & 0.41 & $<20$ & $<20$ & 80 & 160 & 2,560 & 2,560 & 320 & 640 & NA & 4 \\
\hline-13 & 0.43 & 0.29 & 0.89 & 1.00 & $<20$ & $<20$ & 40 & 40 & 640 & 640 & 320 & 320 & $<4$ & 4 \\
\hline-14 & 0.09 & 0.14 & 0.47 & 0.41 & $<20$ & $<20$ & $<20$ & $<20$ & 1,280 & 5,120 & 320 & 640 & NA & NA \\
\hline-15 & 0.07 & 0.13 & 0.30 & 0.50 & $<20$ & $<20$ & $<20$ & $<20$ & 640 & 1,280 & 80 & 160 & NA & NA \\
\hline-16 & 0.76 & 0.59 & 1.04 & 0.79 & $<20$ & $<20$ & $<20$ & $<20$ & 5,120 & 5,120 & 80 & 160 & $<4$ & 4 \\
\hline-17 & 0.00 & 0.03 & 0.63 & 0.79 & $<20$ & $<20$ & $<20$ & $<20$ & NA & NA & NA & NA & $<4$ & $<4$ \\
\hline-18 & 0.00 & 0.06 & 0.29 & 0.27 & $<20$ & $<20$ & $<20$ & $<20$ & 2,560 & 5,120 & 40 & 80 & $<4$ & 4 \\
\hline-19 & 0.58 & $0.78^{\ddagger \ddagger}$ & 0.60 & 0.82 & $<20$ & $<20$ & 640 & 320 & 5,120 & 5,120 & 320 & 320 & 8 & 4 \\
\hline
\end{tabular}

Cohort II

\begin{tabular}{|c|c|c|c|c|c|c|c|c|c|c|c|c|c|c|}
\hline $7002-1$ & 0.04 & 0.15 & 0.32 & 0.41 & $<20$ & $<20$ & 20 & 20 & 5,120 & 10,240 & 80 & 80 & 4 & 8 \\
\hline-2 & 0.01 & $0.25^{\ddagger \ddagger}$ & 0.49 & 0.78 & $<20$ & $<20$ & $<20$ & $<20$ & 160 & 320 & 20 & 20 & 4 & 4 \\
\hline-4 & 0.00 & 0.10 & 0.26 & 0.47 & 20 & $320^{\#}$ & 20 & 40 & 640 & 640 & 160 & 40 & $<4$ & $<4$ \\
\hline-5 & 0.00 & 0.01 & 0.20 & 0.45 & $<20$ & $<20$ & 20 & 40 & 640 & 1,280 & 160 & 80 & $<4$ & $<4$ \\
\hline-6 & 0.12 & 0.12 & 0.34 & $1.00^{\ddagger}$ & $<20$ & $<20$ & $<20$ & $<20$ & 5,120 & 2,560 & 160 & 160 & 4 & 4 \\
\hline-8 & 0.09 & 0.12 & 0.23 & 0.42 & $<20$ & $<20$ & $<20$ & $<20$ & 320 & 320 & 160 & 160 & 32 & 32 \\
\hline-9 & 0.10 & 0.07 & 0.21 & $0.66^{\ddagger}$ & $<20$ & $<20$ & $<20$ & $<20$ & 2,560 & 2,560 & 160 & 320 & 4 & $64^{\# \#}$ \\
\hline-10 & 0.91 & 1.04 & 1.44 & 0.89 & 40 & 40 & $<20$ & $<20$ & 2,560 & 5,120 & 160 & 160 & NA & $<4$ \\
\hline-11 & 0.05 & 0.08 & 0.42 & 0.58 & $<20$ & 40 & 20 & $<20$ & 1,280 & 2,560 & 80 & 80 & 16 & 16 \\
\hline-12 & NA & 0.05 & NA & NA & NA & $<20$ & NA & $<20$ & 2,560 & 2,560 & 160 & 320 & NA & NA \\
\hline $\begin{array}{l}\text { ohort III } \\
7003-1\end{array}$ & 0.02 & 0.16 & 0.81 & 0.96 & $<20$ & $160^{\# \pm}$ & $<20$ & $<20$ & 1,280 & 2,560 & 80 & 160 & $<4$ & $<4$ \\
\hline-4 & 0.09 & 0.13 & 0.34 & 0.56 & $<20$ & $40^{\ddagger}$ & $<20$ & $<20$ & 5,120 & 5,120 & 320 & 320 & $<4$ & $<4$ \\
\hline-5 & 0.08 & $0.36^{\ddagger \pm}$ & 0.37 & 0.62 & $<20$ & $<20$ & $<20$ & $<20$ & 640 & 1,280 & 160 & 320 & NA & NA \\
\hline-6 & 0.21 & 0.21 & 0.89 & 0.51 & $<20$ & $<20$ & $<20$ & 20 & 1,280 & 2,560 & 320 & 320 & NA & 4 \\
\hline-8 & 1.04 & 0.92 & 0.42 & 0.40 & $<20$ & 160 & $<20$ & 20 & 640 & 1,280 & 80 & 320 & NA & 4 \\
\hline-9 & 0.72 & 0.71 & 0.33 & 0.38 & $<20$ & $<20$ & $<20$ & $<20$ & 640 & 640 & 320 & 160 & 4 & 4 \\
\hline-10 & 0.00 & 0.00 & 0.11 & 0.16 & $<20$ & $<20$ & $<20$ & $<20$ & 1,280 & 640 & 20 & 40 & NA & NA \\
\hline-12 & 0.00 & 0.06 & 0.29 & 0.29 & $<20$ & $<20$ & $<20$ & $<20$ & 1,280 & 1,280 & 160 & 320 & $<4$ & $<4$ \\
\hline
\end{tabular}

* A rise in net optical density $\geq 0.15$ of the postvaccination over the prevaccination specimen is significant. ${ }^{\ddagger} \mathrm{A}$ rise in net optical density $\geq 0.40$ of the postvaccination over the prevaccination specimen is significant. "Fourfold or greater rise in titer is significant. "Prevaccination titer.

' Peak postvaccination titer. ** Specimen not available or test not done. " Significant rise over prevaccination titer. 
Table IV. Replication Responses of Pre-and Postvaccination Lymphocytes to Culture Medium Alone or Mitogens

\begin{tabular}{|c|c|c|c|c|c|c|c|c|c|c|c|}
\hline \multirow[b]{3}{*}{ Vaccinee ${ }^{4}$} & \multirow{2}{*}{\multicolumn{3}{|c|}{$\begin{array}{l}\text { Mean counts per minute } \\
\text { per culture* } \\
\text { No antigen }\end{array}$}} & \multicolumn{8}{|c|}{ Net counts per minute per culture for cultures stimulated with: } \\
\hline & & & & \multicolumn{4}{|l|}{ PHA } & \multicolumn{4}{|l|}{ PWM } \\
\hline & $-1^{4}$ & 22 & $61^{\prime \prime}$ & -1 & 22 & 61 & $R^{\prime}$ & -1 & 22 & 61 & $\mathbf{R}$ \\
\hline \multicolumn{12}{|l|}{ Cohort I } \\
\hline 1 & 518 & 366 & ND & 59,183 & 93,965 & ND & & 13,035 & 34,492 & ND & \\
\hline 2 & 548 & 364 & ND & 127,159 & 80,920 & ND & & 19,834 & 23,154 & ND & \\
\hline 3 & 288 & 166 & ND & 133,524 & 67,476 & ND & & 39,279 & 41,527 & ND & \\
\hline 4 & 178 & 149 & ND & 132,442 & 108,504 & ND & & 38,013 & 25,976 & ND & \\
\hline 5 & 207 & 519 & ND & 73,495 & 87,903 & ND & & 30,003 & 14,389 & ND & \\
\hline 6 & 681 & 298 & ND & 138,658 & 88,934 & ND & & 29,263 & 24,912 & ND & \\
\hline 7 & 562 & 275 & ND & 49,793 & 56,335 & ND & & 16,734 & 28,320 & ND & \\
\hline 8 & 215 & 208 & ND & 135,441 & 64,086 & ND & & 31,349 & 25,798 & ND & \\
\hline 9 & 326 & 416 & ND & 146,112 & 70,870 & ND & & 41,386 & 46,156 & ND & \\
\hline 10 & 367 & 497 & ND & 74,651 & 38,478 & ND & & 29,768 & 41,640 & ND & \\
\hline 11 & 545 & 298 & ND & 73,499 & 71,442 & ND & & 20,073 & 31,514 & ND & \\
\hline 12 & 385 & 457 & ND & 110,898 & 86,512 & ND & & 19,279 & 20,375 & ND & \\
\hline 13 & 156 & 369 & ND & 62,794 & 70,598 & ND & & 36,189 & 28,874 & ND & \\
\hline 14 & 301 & 935 & ND & 101,806 & 86,822 & ND & & 28,735 & 28,619 & ND & \\
\hline 15 & 407 & 314 & ND & 72,637 & 96,644 & ND & & 13,503 & 19,786 & ND & \\
\hline 16 & 523 & 364 & ND & 81,065 & 82,095 & ND & & 24,541 & 20,974 & ND & \\
\hline 17 & 275 & 224 & ND & 99,507 & 59,634 & ND & & $3,872 !^{* *}$ & $4,343 !$ & ND & $!$ \\
\hline 18 & 654 & 269 & ND & 134,561 & 65,989 & ND & & 33,042 & 28,831 & ND & \\
\hline Mean & 396 & 360 & & 100,401 & 76,512 & & & 25,994 & 27,204 & & \\
\hline SD & 166 & 178 & & 32,386 & 16,895 & & & 10,313 & 10,016 & & \\
\hline \multicolumn{4}{|c|}{ No. with significant difference ${ }^{\ddagger \ddagger}$} & 0 & 0 & & 0 & 1 & 1 & & 1 \\
\hline \multicolumn{4}{|c|}{$\%$ with significant difference } & 0 & 0 & & 0 & 6 & 6 & & 6 \\
\hline \multicolumn{12}{|c|}{ Cohort II } \\
\hline 1 & 253 & 490 & 592 & 77,604 & 129,766 & 113,527 & & 26,273 & 25,040 & 31,461 & \\
\hline 2 & 480 & 142 & 822 & 123,382 & $161,851 !$ & 106,286 & $!$ & 31,945 & 10,734 & 32,480 & \\
\hline 4 & 723 & 420 & 363 & 131,469 & 124,448 & 79,352 & & 25,589 & 43,960 & 22,701 & \\
\hline 5 & 574 & 503 & 1,283 & 34,154 & 42,203 & 35,816 & & 35,306 & 30,487 & 15,478 & \\
\hline 6 & 1,057 & 566 & 824 & 85,656 & 107,818 & 71,718 & & $67,004 !$ & $67,640 !$ & 30,313 & $!$ \\
\hline 8 & 726 & 637 & 1,418 & 100,638 & 124,926 & 94,230 & & 55,479 & 54,457 & 37,249 & \\
\hline 9 & 301 & 160 & 1,416 & 92,283 & 99,230 & 84,245 & & 34,922 & 39,800 & 25,606 & \\
\hline 10 & 206 & 185 & 379 & 67,642 & 101,748 & 113,551 & & 31,284 & 35,811 & 18,013 & \\
\hline 11 & 287 & 283 & 688 & 73,479 & 93,858 & 77,706 & & 36,119 & 35,557 & 26,363 & \\
\hline 12 & 671 & 241 & & 53,757 & 124,046 & & & 21,483 & 23,119 & & \\
\hline Mean & 528 & 363 & 865 & 84,006 & 110,989 & 86,270 & & 36,540 & 36,661 & 26,629 & \\
\hline SD & 273 & 182 & 416 & 29,760 & 31,170 & 24,581 & & 14,110 & 16,228 & 7,063 & \\
\hline \multicolumn{4}{|c|}{ No. with significant difference } & 0 & 1 & 0 & 1 & 1 & 1 & 0 & 1 \\
\hline \multicolumn{4}{|c|}{$\%$ with significant difference } & 0 & 10 & 0 & 10 & 10 & 10 & 0 & 10 \\
\hline \multicolumn{12}{|c|}{ Cohort III } \\
\hline 1 & & 219 & 550 & & 74,156 & 79,950 & & & 15,800 & 17,832 & \\
\hline 4 & 795 & 259 & 748 & 136,986 & 140,482 & 79,045 & & 23,529 & 19,434 & 23,768 & \\
\hline 5 & 383 & 600 & & 86,956 & 131,930 & & & 20,980 & 12,398 & & \\
\hline 6 & 546 & 170 & 332 & 75,898 & 44,248 ! & 75,845 & $!$ & 24,246 & 24,677 & 25,518 & \\
\hline 8 & & 146 & 512 & & 62,693 & 107,471 & & & 28,291 & 34,693 & \\
\hline 9 & 498 & 242 & 528 & 81,742 & 127,404 & 116,775 & & 41,391 & 30,622 & 31,197 & \\
\hline 10 & 574 & 128 & 193 & 104,036 & 99,026 & 107,958 & & 20,061 & 20,708 & 15,099 & \\
\hline 12 & 538 & 205 & 514 & 98,345 & 90,895 & 107,136 & & 11,028 & 11,397 & 16,067 & \\
\hline Mean & 556 & 246 & 482 & 97,327 & 96,354 & 96,311 & & 23,539 & 20,416 & 23,453 & \\
\hline SD & 135 & 150 & 176 & 22,039 & 34,959 & 17,228 & & 9,943 & 7,094 & 7,601 & \\
\hline
\end{tabular}




\begin{tabular}{|c|c|c|c|c|c|c|c|c|}
\hline & \multicolumn{4}{|l|}{ PHA } & \multicolumn{4}{|l|}{ PWM } \\
\hline & -1 & 22 & 61 & $R^{\prime}$ & -1 & 22 & 61 & $\mathbf{R}$ \\
\hline No. with significant difference & 0 & 1 & 0 & 1 & 0 & 0 & 0 & 0 \\
\hline$\%$ with significant difference & 0 & 12 & 0 & 12 & 0 & 0 & 0 & 0 \\
\hline For all cohorts & & & & & & & & \\
\hline $\begin{array}{l}\text { No. with significant difference/no. } \\
\text { of vaccinees }\end{array}$ & $0 / 34$ & $2 / 36$ & $0 / 16$ & $2 / 36$ & $2 / 34$ & $2 / 36$ & $0 / 16$ & $2 / 36$ \\
\hline Percent with significant difference & 0 & 6 & 0 & 6 & 6 & 6 & 0 & 6 \\
\hline
\end{tabular}

ND, not done. * Mean counts per minute of triplicate cultures. ${ }^{*}$ The number of vaccinees tested differs from the total number of volunteers because of failure to obtain some postvaccination samples and occasional technical problems with individual assays. "Interval in days in relation to vaccination. "Individuals in cohort III were evaluated at day 93 after vaccination. 'Responders (see below) on either day 22 or 61 postvaccination. **! denotes responders, defined as those individuals whose average net counts per minute per culture for triplicate cultures was more than 2 SD above or below the prevaccination mean counts per minute per culture of the cohort. \# Total number of individuals meeting the definition of responder.

by hydrolyzing phosphate bonds and fatty acid-ester linkages in the lipid moiety of the LPS by treatment with $\mathrm{NaOH}\left(0.15 \mathrm{M}, 100^{\circ} \mathrm{C}, 2 \mathrm{~h}\right)$. After centrifugation, the $\mathrm{pH}$ was brought to 3.5 and free fatty acids were removed by successive extractions with chloroform. The $\mathrm{pH}$ was then adjusted to 7.0, and the material was dialyzed against distilled water and lyophilized. O polysaccharides were then prepared by hydrolysis of the partially delipidated LPS with weak acetic acid $\left(1 \%, 100^{\circ} \mathrm{C}, 1 \mathrm{~h}\right)$. The reaction mixture was extracted with chloroform after which the water phase was dialyzed extensively against distilled water and lyophilized. The various $O$ polysaccharides were at least $99.9 \%$ pure from contaminating protein or lipid.

After $3 \mathrm{~d}$ of incubation in the presence of PHA, $5 \mathrm{~d}$ with PWM, or $7 \mathrm{~d}$ with antigen, tritiated thymidine $(0.5 \mu \mathrm{Ci}$ per culture) was added to the cultures. On the day after addition of thymidine, an automated harvesting device (PHD Cell Harvestor, Cambridge, MA) was used to collect mononuclear cells onto glass filters. Standard liquid scintillation procedures were employed to quantitate the amount of thymidine incorporated.

For each vaccinee's specimens, at each time point, the average counts per minute per culture for a triplicate set of cultures without antigen was subtracted from the average of every triplicate with antigen or mitogen and the resultant value referred to as the net counts per minute per culture. For each antigen used in the lymphocyte replication assay, a cohort mean \pm standard deviation was calculated from the prevaccination net counts per minute per culture of the individuals in the cohort (i.e., group of volunteers vaccinated at the same time) and this prevaccination mean was used as the basis for identification of "responders." Thereafter, a responder was defined as an individual whose triplicate mononuclear cell cultures incubated with antigen gave a net counts per minute per culture that exceeded by 2 SD the mean net counts per minute per culture for that antigen in the individual's cohort before vaccination.

$S$. typhi growth inhibition assay. The Salmonella growth inhibition assay was modeled after that of Nencioni et al. (30). Except for the periods of incubaton, all procedures were carried out at $4^{\circ} \mathrm{C}$ with chilled $\left(4^{\circ} \mathrm{C}\right)$ reagents. Frozen seed stock of Vi-positive S. typhi 5077 (a representative wild-type strain isolated from the blood of a child with typhoid fever in Santiago, Chile) was thawed, inoculated into antibiotic medium 3 (Difco Laboratories), and incubated with agitation for $6 \mathrm{~h}$ at $37^{\circ} \mathrm{C}$, and the concentration of bacteria was determined photometrically. The $S$. typhi were washed, centrifuged, and resuspended in RPMI 1640 supplemented with $0.25 \mathrm{mM}$ Hepes and bicarbonate at $4^{\circ} \mathrm{C}$. Thereupon the $S$. typhi ( $10^{4}$ colony-forming units [CFU]) were deposited by centrifugation on the bottom of sterile $12 \times 75-\mathrm{mm}$ polypropylene tubes. To separate tubes containing bacteria, either the culture medium alone, $2 \times 10^{6}$ mononuclear cells (obtained identically as described for lymphocyte replication studies), a 1:2,000 dilution of (heat-inactivated) plasma, or a mixture of mononuclear cells and plasma from the same vaccinee, were added. The tubes were so prepared in triplicate. At this point, $0.5 \mathrm{ml}$ of the culture medium, supplemented with $32 \%$ heat-inactivated fetal calf serum (Gibco), was added to each tube. The tubes were incubated for $60 \mathrm{~min}$ in a water bath at $37^{\circ} \mathrm{C}$. Thereupon, to determine the inhibitory effects of plasma or mononuclear cells, alone or in combination, each tube was vigorously shaken and serial 10 -fold dilutions were inoculated onto trypticase soy agar and the number of CFU that grew after overnight incubation at $37^{\circ} \mathrm{C}$ were counted; these quantitative cultures from each tube were made in duplicate and the mean was computed.

To simplify analysis of the data, the mean number of CFU in the tubes containing cells, plasma, or the combination were compared with the corresponding tubes with culture medium alone and expressed as a percent "growth inhibition", i.e., $100-(100)$ (CFU of experimental tube/CFU of control tube). Three cohorts of vaccinees were given one of the vaccines in varying doses (see Results). The mean percent growth inhibition ( \pm standard deviation) was calculated for each cohort for plasma alone, cells alone and the combination in the specimens collected before vaccination. Results of the growth inhibition assays of each individual before and after vaccination were compared with the mean growth inhibition of that individual's cohort before vaccination. In this manner responders were identified, defined as any individual whose $S$. typhi growth inhibition assay value exceeded by 2 SD the mean of his cohort prevaccination.

\section{Results}

\section{Clinical response}

Three separate vaccination studies were carried out over several months with three cohorts of volunteers wherein various doses of the two vaccine strains were administered. In the first study, a cohort of 19 individuals ingested a single $10^{8}$ organism dose of strain 541Ty or 543Ty. A single $10^{9}$ organism dose of one or the other strain was given to 10 volunteers in the second study. In the final study four volunteers ingested a single $10^{10}$ dose of $541 \mathrm{Ty}$, whereas four others ingested $10^{9}$ organisms on two oc- 


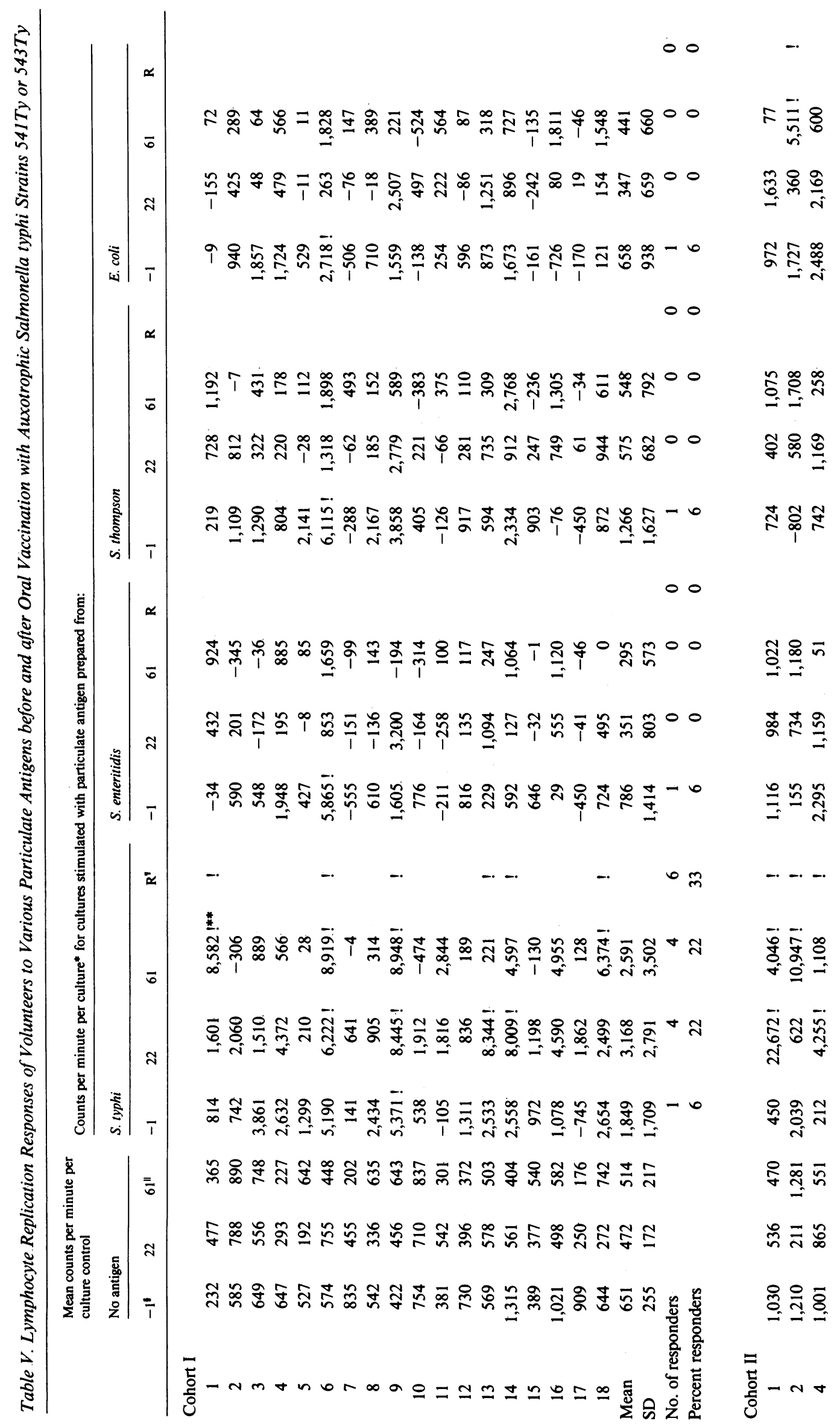




$$
-9
$$

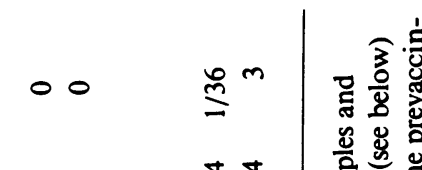

\&

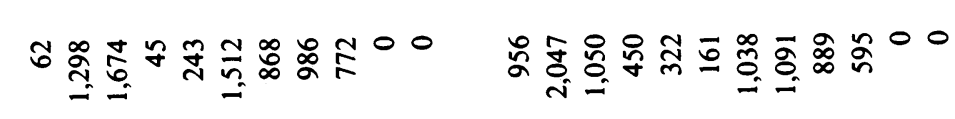

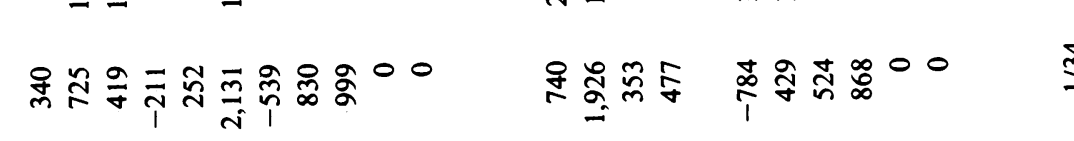

$$
\text { - } 0100
$$

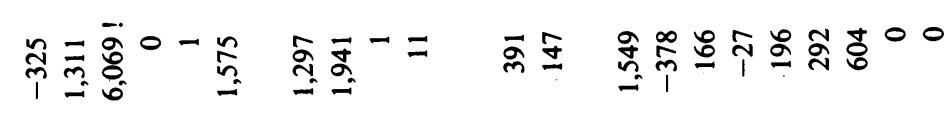

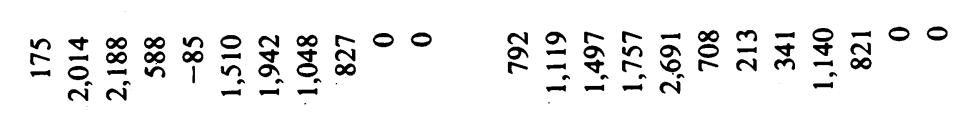

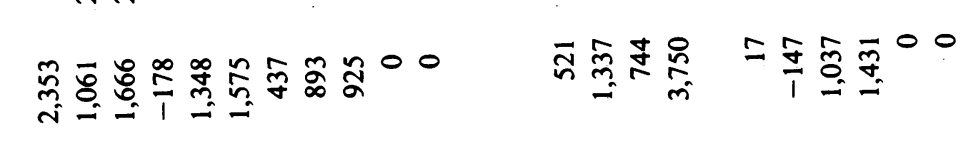

$$
-0
$$$$
\circ \circ
$$

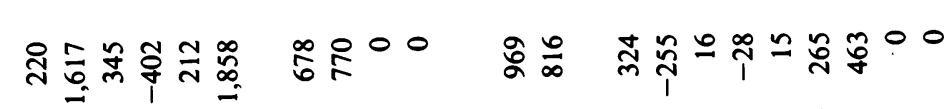

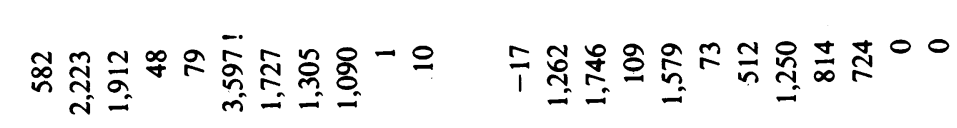

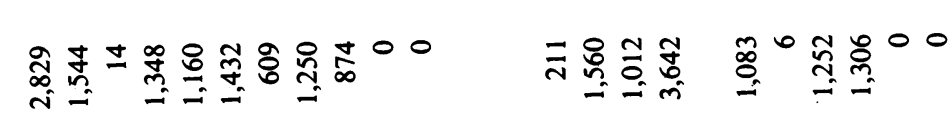

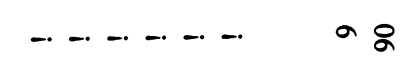

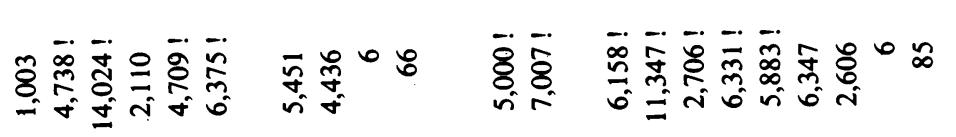

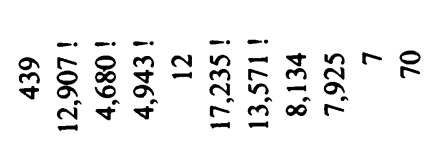

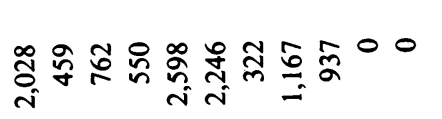

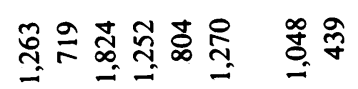

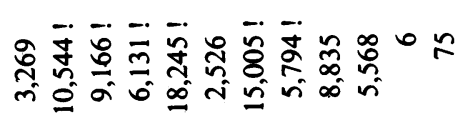

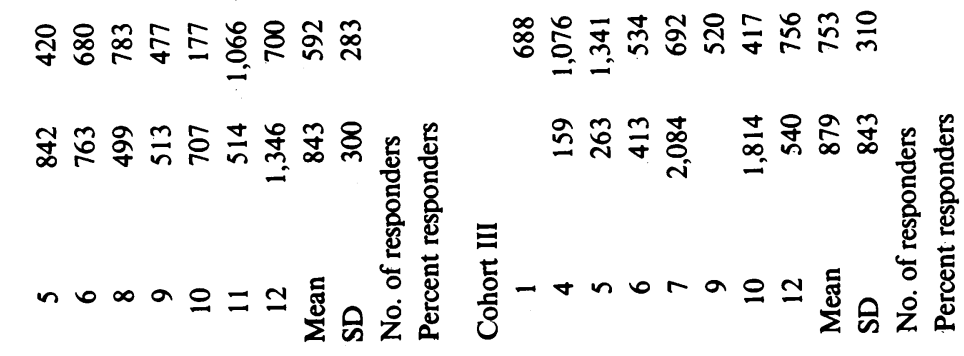

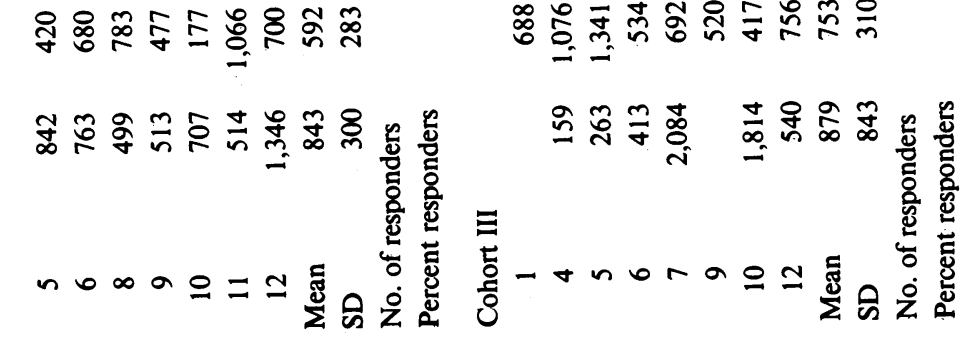

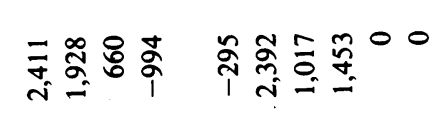

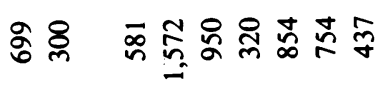

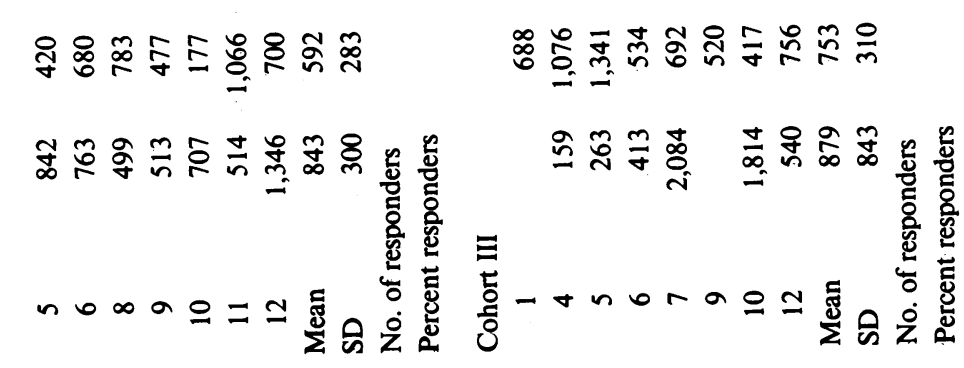

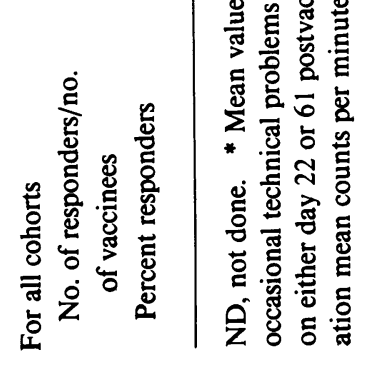


Table VI. Lymphocyte Replication Responses of Volunteers to Various Polysaccharide Antigens

before and after Oral Vaccination with Auxotrophic Salmonella typhi Strains 541Ty or 543Ty

\begin{tabular}{|c|c|c|c|c|c|c|c|c|c|c|c|c|c|c|c|c|}
\hline \multirow[b]{3}{*}{ Vaccinee $^{t}$} & \multicolumn{16}{|c|}{ Counts per minute per cultures* for cultures stimulated with $O$ polysaccharide antigen prepared from: } \\
\hline & \multicolumn{4}{|l|}{ S. typhi } & \multicolumn{4}{|c|}{ S. enteritidis } & \multicolumn{4}{|c|}{ S. thompson } & \multicolumn{4}{|c|}{ S. anatum } \\
\hline & $-1^{4}$ & 22 & $61^{\prime \prime}$ & $\mathbf{R}^{\prime}$ & -1 & 22 & 61 & $\mathbf{R}$ & -1 & 22 & 61 & $\mathbf{R}$ & -1 & 22 & 61 & $\mathbf{R}$ \\
\hline \multicolumn{17}{|l|}{ Cohort I } \\
\hline 1 & 281 & -116 & 932 & & -12 & 0 & 387 & & ND & ND & ND & & 579 & 204 & 630 & \\
\hline 2 & 1,536 & 12 & 249 & & 370 & -213 & -367 & & ND & ND & ND & & 662 & 357 & 89 & \\
\hline 3 & 838 & $1,784 ! * *$ & 661 & $!$ & -23 & 321 & 239 & & ND & ND & ND & & 1,431 & 747 & 215 & \\
\hline 4 & 1,415 & 12 & 106 & & -108 & -78 & -24 & & ND & ND & ND & & 934 & 52 & 262 & \\
\hline 5 & 55 & 18 & 110 & & 621 & 18 & -173 & & ND & ND & ND & & 391 & 20 & 243 & \\
\hline 6 & 589 & 815 & $4,613 !$ & $!$ & 106 & 51 & 98 & & ND & ND & ND & & 1,670 & 1,403 & 2,036 & \\
\hline 7 & -229 & 124 & 280 & & 773 & -170 & -81 & & ND & ND & ND & & 93 & 120 & 50 & \\
\hline 8 & 574 & 5 & -86 & & 335 & -61 & -247 & & ND & ND & ND & & 1,773 & 145 & $2,359 !$ & $!$ \\
\hline 9 & 1,406 & 629 & $2,154 !$ & $!$ & 39 & 50 & -119 & & ND & ND & ND & & 949 & 988 & 389 & \\
\hline 10 & 227 & 272 & 411 & & -147 & 266 & 723 & & ND & ND & ND & & 1,107 & 115 & -120 & \\
\hline 11 & -5 & -19 & -57 & & 88 & -88 & 51 & & ND & ND & ND & & 39 & -215 & 244 & \\
\hline 12 & 30 & 91 & $2,521 !$ & $!$ & 81 & 162 & 234 & & ND & ND & ND & & 296 & 717 & 1,639 & \\
\hline 13 & -15 & $2,762 !$ & 1,453 & $!$ & -88 & 32 & $1,130 !$ & $!$ & ND & ND & ND & & 1,180 & 503 & 1,773 & \\
\hline 14 & 321 & $2,588 !$ & 1,425 & $!$ & 477 & 111 & 370 & & ND & ND & ND & & 2,326 & 881 & 1,282 & \\
\hline 15 & 134 & 352 & 794 & & 116 & 166 & 744 & & ND & ND & ND & & 20 & 600 & 721 & \\
\hline 16 & -150 & -108 & $2,878 !$ & $!$ & -191 & -23 & 278 & & ND & ND & ND & & 887 & 1,353 & 1,598 & \\
\hline 17 & -679 & 263 & 144 & & 686 & 248 & 250 & & ND & ND & ND & & 586 & 394 & 434 & \\
\hline 18 & 618 & 1,131 & 1,515 & & -147 & 367 & 406 & & ND & ND & ND & & 965 & 878 & 1,090 & \\
\hline Mean & 386 & 590 & 1,117 & & 165 & 64 & 217 & & ND & ND & ND & & 883 & 515 & 830 & \\
\hline SD & 604 & 904 & 1,257 & & 305 & 165 & 381 & & ND & ND & ND & & 634 & 464 & 769 & \\
\hline $\begin{array}{l}\text { No. of } \\
\text { responders }\end{array}$ & & & & & & & & & & & & & & & & \\
\hline $\begin{array}{l}\text { responders } \\
\text { Percent }\end{array}$ & 0 & 3 & 4 & 7 & 0 & 0 & 1 & 1 & & & & 0 & 0 & 1 & 1 & \\
\hline responders & 0 & 17 & 22 & 39 & 0 & 0 & 6 & 6 & & & & 0 & 0 & 6 & 6 & \\
\hline \multicolumn{17}{|l|}{ Cohort II } \\
\hline 1 & -596 & $6,137 !$ & $1,869 !$ & $!$ & -591 & -257 & 69 & & -178 & -125 & 490 & & ND & ND & ND & \\
\hline 2 & -380 & $1,481 !$ & $4,741 !$ & ! & -352 & -4 & 233 & & 192 & 148 & 606 & & ND & ND & ND & \\
\hline 4 & -189 & 1,000 & 1,140 & & -231 & -301 & 152 & & 147 & -278 & 784 & & ND & ND & ND & \\
\hline 5 & 1,246 & 228 & -12 & & -384 & -49 & 68 & & -564 & 187 & $857 !$ & & ND & ND & ND & \\
\hline 6 & 465 & $6,430 !$ & $2,544 !$ & $!$ & 198 & -305 & $1,186 !$ & & 725 & 658 & 526 & $!$ & ND & ND & ND & \\
\hline 8 & -140 & $6,718 !$ & $2,674 !$ & & -283 & -575 & -141 & $!$ & -200 & -66 & -245 & & ND & ND & ND & \\
\hline 9 & -231 & 295 & 484 & $!$ & -386 & $455 !$ & -384 & & -140 & 304 & -204 & & ND & ND & ND & \\
\hline 10 & 591 & -38 & 460 & & -444 & -52 & -145 & $!$ & 44 & 12 & -293 & & ND & ND & ND & \\
\hline 11 & 795 & $3,824 !$ & $2,579 !$ & & -224 & -582 & -22 & & 127 & 227 & & & ND & ND & ND & \\
\hline 12 & -558 & 115 & & $!$ & $-93 i$ & 79 & & & 418 & 507 & & & ND & ND & ND & \\
\hline Mean & 100 & 2,619 & 1,831 & & -363 & -159 & 113 & & 57 & 157 & 307 & & ND & ND & ND & \\
\hline SD & 630 & 2,858 & 1,492 & & 287 & 313 & 443 & & 358 & 287 & 451 & & ND & ND & ND & \\
\hline $\begin{array}{l}\text { No. of } \\
\text { responders }\end{array}$ & & & & & & & & & & & & & & & & \\
\hline $\begin{array}{l}\text { responders } \\
\text { Percent }\end{array}$ & 0 & 5 & 5 & 5 & 0 & 1 & 1 & 2 & 0 & 0 & 1 & 1 & & & & \\
\hline responders & 0 & 50 & 50 & 50 & 0 & 10 & 0 & 20 & 0 & 0 & 10 & 10 & & & & \\
\hline \multicolumn{17}{|l|}{ Cohort III } \\
\hline 1 & & 601 & -122 & & & -301 & 93 & & & -131 & 291 & & ND & ND & ND & \\
\hline 4 & 76 & $7,180 !$ & $1,054 !$ & $!$ & -58 & -357 & 46 & & 1,819 & 386 & 582 & & ND & ND & ND & \\
\hline 5 & 317 & $1,562 !$ & & $!$ & -17 & -242 & & & 1,218 & -104 & & & ND & ND & ND & \\
\hline 6 & -86 & 553 & $1,117 !$ & $!$ & 73 & 46 & -30 & & 48 & -202 & -47 & & ND & ND & ND & \\
\hline 8 & & 223 & 433 & & & -321 & -276 & & & -89 & -450 & & ND & ND & ND & \\
\hline 9 & 345 & $1,536 !$ & $2,403 !$ & $!$ & $-1,065$ & 637 & -24 & & -691 & 132 & -351 & & ND & ND & ND & \\
\hline 10 & -658 & $1,446 !$ & $1,199 !$ & ! & $-1,400$ & -86 & -91 & & $-1,321$ & -220 & 428 & & ND & ND & ND & \\
\hline 12 & 550 & $1,112 !$ & 168 & $!$ & -315 & -215 & -120 & & -37 & -328 & 554 & & ND & ND & ND & \\
\hline Mean & 91 & 1,777 & 893 & & -464 & -105 & -57 & & 173 & -70 & 144 & & & & & \\
\hline $\begin{array}{l}\text { SD } \\
\text { No. of }\end{array}$ & 429 & 2,241 & 838 & & 618 & 328 & 121 & & 1,170 & 227 & 428 & & & & & \\
\hline responders & $\mathbf{0}$ & 5 & 4 & 6 & 0 & 0 & 0 & 0 & 0 & 0 & 0 & 0 & & & & \\
\hline $\begin{array}{l}\text { Percent } \\
\text { responders }\end{array}$ & & & & & & & & & & & & & & & & \\
\hline \multirow{2}{*}{\multicolumn{17}{|c|}{$\begin{array}{l}\text { For all cohorts } \\
\text { No. of } \\
\text { responders/ } \\
\text { no. of }\end{array}$}} \\
\hline & & & & & & & & & & & & & & & & \\
\hline $\begin{array}{l}\text { vaccinees } \\
\text { Percent }\end{array}$ & $0 / 34$ & $13 / 36$ & $13 / 34$ & $18 / 36$ & $0 / 34$ & $1 / 36$ & $2 / 34$ & $3 / 36$ & $0 / 16$ & $0 / 18$ & $1 / 16$ & $1 / 18$ & $0 / 18$ & $0 / 18$ & $1 / 18$ & $1 / 18$ \\
\hline responders & 0 & 36 & 38 & 50 & 0 & 3 & 6 & 8 & 0 & 0 & 6 & 6 & 0 & 0 & 6 & 6 \\
\hline
\end{tabular}

ND, not done. * Mean value of triplicate cultures. ${ }^{\ddagger}$ The number of vaccinees tested differs from the total number of volunteers because of failure to obtain some postvaccination samples and occasional technical problems with individual assays. "Interval in days in relation to vaccination. "Individuals in cohort III were evaluated at day 93 after vaccination. 'Responders (see below) on either day 22 or 61 postvaccination. ** ! denotes responders, who are those individuals whose average net counts per minute per culture for triplicate cultures exceeded by 2 SD the prevaccination mean counts per minute per culture of the cohort. 
casions, $4 \mathrm{~d}$ apart. The vaccine strains were very well tolerated, with none of the vaccinees exhibiting notable adverse reactions during the $15 \mathrm{~d}$ of clinical observation after vaccination (Table I). Clinical signs and symptoms of enteric fever, such as fever, diarrhea, or abdominal discomfort were not encountered. No volunteer's temperature exceeded $37.7^{\circ} \mathrm{C}$. The vaccinees were not given antibiotics and no complaints of adverse reactions were reported at follow-up visits 7 and $14 \mathrm{~d}$ after discharge from the research isolation ward.

\section{Bacteriology}

Bacteriologic results are summarized in Table II and Fig. 1. The rate of positive coprocultures, the geometric mean titer of vaccine organisms excreted per gram of stool, and the duration of shedding increased as the vaccine dose increased. All positive coprocultures occurred within the first $96 \mathrm{~h}$ after ingestion of vaccine. S-S agar proved to be superior for isolation of the vaccine strains. Isolates recovered from individuals who ingested 541Ty were $\mathrm{Vi}$-positive, whereas isolates recovered from recipients of strain 543Ty were Vi-negative.

Two individuals who ingested strain 541Ty, including one who received $10^{10}$ and another who received two $10^{9}$ organism doses, had recovery of the vaccine organism from bile-stained duodenal string cultures. In both instances the vaccine strain was recovered within $48 \mathrm{~h}$ of ingestion of the vaccine. In one of these individuals the vaccine strain was not recovered in coprocultures. Of the 259 blood cultures systematically collected from the vaccinees, beginning $24 \mathrm{~h}$ after ingestion of the vaccine and continuing every other day for $2 \mathrm{wk}$, none were positive.

\section{Serology}

Results of the serum antibody assays are summarized in Table III. By serologic tests the vaccines did not appear to stimulate a potent humoral antibody response, either of circulating or local intestinal antibody. A small proportion of vaccinees manifested rises in serum or intestinal fluid antibody to $S$. typhi $\mathrm{O}$ antigen or serum antibody to $H$ or lysate antigen. None of the 37 vaccinees manifested significant rises in serum $\mathrm{Vi}$ antibody.

\section{Cell-mediated immune responses}

In contrast to the humoral antibody responses, which were meager, the assays for cell-mediated immunity demonstrated a prominent and specific response that correlated with the dose of vaccine ingested (see Tables V-VII).

Lymphocyte replication assays. Vaccination did not significantly alter the basal rate of lymphocyte replication in vitro, in comparison with prevaccination values (Table IV). Similarly, the nonspecific mitogenic response of lymphocytes to PHA and PWM was not significantly affected by vaccination (Table IV).

The prevaccination, mean cohort values \pm standard deviation for lymphocyte reactivity in the presence of heat-phenolized bacterial antigen and $O$ polysaccharide antigens are shown in Tables V and VI. In specimens collected before vaccination from 34 individuals, lymphocyte reactivity was similarly rare after incubation with $S$. typhi (1 of 34), S. enteritidis (1 of 34), $S$. thompson (1 of 34), or E. coli (1 of 34) particulate antigens (Table $\mathrm{V})$ or following incubation with $\mathrm{O}$ polysaccharide antigens of $S$. typhi (0 of 34), $S$. enteritidis (0 of 34), S. thompson (0 of 16), or $S$. anatum (0 of 18) (Table VI). In contrast, both particulate preparation and purified $O$ polysaccharide of $S$. typhi stimulated significant reactivity of the lymphocytes of most vaccinees in specimens collected 22 and 61-96 d after vaccination (Tables
V and VI). These responses were specific, because there was not a corresponding increase in reactivity of lymphocytes to the control antigens from $E$. coli and other Salmonella, including serologically closely related $S$. enteritidis (Tables V and VI). The rate of responders detected after incubation of postvaccination lymphocytes with $S$. typhi particulate antigen (22 of 36) is significantly different than the rate encountered following incubation of postvaccination lymphocytes with $S$. enteritidis (1 of 36), S. thompson (1 of 36), or $E$. coli (1 of 36) particulate antigens $(P<0.0000001$ for each comparison, Fishers exact test, two tails) (Table V). The difference in response of postvaccination lymphocytes to the $O$ polysaccharide antigens was equally notable. Postvaccination lymphocytes of 18 of 36 vaccinees responded to $S$. typhi O polysaccharide but only 3 of 36 to $S$. enteritidis and 2 of 36 to $S$. thompson or $S$. anatum $O$ polysaccharides $(P<0.0002$ for each comparison) (Table VI). There was no difference between the two vaccines in immunogenicity.

$S$. typhi growth inhibition assay. In specimens collected before vaccination there was virtually no inhibitory effect observed when plasma alone, mononuclear cells alone, or the combination were incubated with $S$. typhi (Table VII).

In contrast, the most sensitive assay to detect immune response to these live oral vaccines turned out to be the $S$. typhi growth inhibition assay using plasma and mononuclear cells collected before vaccination and 22 and $61 \mathrm{~d}$ thereafter. With only two exceptions, postvaccination plasma alone had no inhibitory activity against a representative wild type $S$. typhi strain (Table VII). In contrast, mononuclear cells from 18 of 35 individuals after vaccination, in the absence of plasma, did significantly inhibit the growth of pathogenic $S$. typhi, particularly with mononuclear cells derived from recipients of higher doses of vaccine (Table VII) $(P<0.000001)$. However, the most prominent inhibition of $S$. typhi growth was detected when an individual's postvaccination plasma was used in combination with his mononuclear cells in the assay. Under these conditions, a plasma-associated mononuclear cell immune response, manifested as inhibition of the growth of pathogenic $S$. typhi, was detected in $100 \%$ of the vaccinees. The effect of the combination of mononuclear cells plus plasma (36 of 36 responders) was significantly greater than the inhibitory effect of cells alone (18 of 36 responders, $P<0.000001$ ).

\section{Discussion}

Considerable evidence supports the contention that live attenuated Salmonella vaccines stimulate superior immunity to that achieved with killed whole cell parenteral vaccines (9, 31-41). Only live $S$. typhimurium vaccines can protect hypersusceptible $\mathrm{C} 3 \mathrm{H} / \mathrm{HeJ}$ mice from an otherwise lethal challenge with virulent S. typhimurium in the "mouse typhoid" model (38-41). Similarly in calves, where $S$. typhimurium often causes a generalized infection of the reticuloendothelial system (and in this feature resembles $S$. typhi infection in humans), in addition to gastroenteritis, an Aro- auxotrophic mutant employed as a live oral vaccine provided significantly greater protection than a killed whole-cell parenteral vaccine (35). By using an experimental model of typhoid fever in volunteers in the late 1960 s and early 1970 s to assess the efficacy of typhoid vaccines $(9,36,37,42)$, it was found that a streptomycin-dependent $S$. typhi vaccine strain $(36,37)$ and Ty21a (9) vaccine given as freshly harvested organisms provided higher levels of protection than parenteral killed whole-cell typhoid vaccines (42). The great advantage of 
Table VII. Salmonella typhi Growth Inhibition Responses of Volunteers after Oral Vaccination with Auxotrophic Salmonella typhi Strains 541Ty or 543Ty

\begin{tabular}{|c|c|c|c|c|c|c|c|c|c|c|c|c|c|c|c|}
\hline \multirow[b]{4}{*}{ Vaccinee* } & \multicolumn{15}{|c|}{ Contents of cultures } \\
\hline & \multicolumn{3}{|c|}{$\begin{array}{l}\text { Control } \\
\text { S. typhi only }\end{array}$} & \multicolumn{12}{|l|}{ S. typhi plus: } \\
\hline & \multirow[b]{2}{*}{$-1^{*}$} & \multirow[b]{2}{*}{22} & \multirow[b]{2}{*}{$61^{4}$} & \multicolumn{4}{|l|}{ Plasma } & \multicolumn{4}{|l|}{ MN cells } & \multicolumn{4}{|c|}{ MN cells + plasma } \\
\hline & & & & -1 & 22 & 61 & $\mathbf{R}^{\prime \prime}$ & -1 & 22 & 61 & $\mathbf{R}$ & -1 & 22 & 61 & $\mathbf{R}$ \\
\hline \multicolumn{16}{|l|}{ Cohort I } \\
\hline 1 & $1.4^{\prime}$ & 1.5 & 2.8 & $7.8^{* *}$ & 2.3 & -8.7 & & 20.5 & $36.8 !^{\ddagger}$ & 3.3 & $!$ & 16.9 & $43.8 !$ & $35.9 !$ & $!$ \\
\hline 2 & 1.3 & 1.6 & 2.7 & -4.9 & 3.9 & 1.1 & & 6.5 & 19.4 & 21.9 & & 4.0 & $41.1 !$ & $56.0 !$ & $!$ \\
\hline 3 & 1.3 & 1.4 & 2.8 & -4.2 & -4.4 & -3.2 & & 9.0 & 20.9 & & & 5.9 & $28.5 !$ & $57.3 !$ & $!$ \\
\hline 4 & 1.4 & 1.6 & 3.9 & 8.4 & 5.2 & 15.3 & & 17.6 & 21.3 & 29.5 & & 15.1 & $35.7 !$ & $35.7 !$ & $!$ \\
\hline 5 & 1.3 & 1.5 & 3.0 & 12.7 & 2.9 & 17.0 & & 3.0 & $37.6 !$ & $41.9 !$ & $!$ & 15.1 & $45.1 !$ & $58.0 !$ & $!$ \\
\hline 6 & 1.2 & 1.5 & 3.5 & -0.4 & -12.7 & 6.8 & & 4.1 & 23.0 & 3.4 & & 5.5 & 12.7 & $50.8 !$ & $!$ \\
\hline 7 & 1.3 & 1.9 & & -30.8 & 15.6 & & & $35.0 !$ & $40.5 !$ & & $!$ & -16.3 & $50.2 !$ & & $!$ \\
\hline 8 & 1.3 & 1.5 & 4.6 & 2.5 & -3.7 & $26.6 !$ & $!$ & -0.8 & -1.2 & $48.0 !$ & $!$ & 5.7 & 16.6 & $66.8 !$ & $!$ \\
\hline 9 & 1.1 & 1.5 & 4.9 & 5.2 & -5.3 & 21.2 & & 1.6 & 17.2 & 21.8 & & -2.4 & $31.4 !$ & $66.7 !$ & $!$ \\
\hline 10 & 1.4 & 1.6 & 2.8 & -2.8 & -3.2 & 18.1 & & 10.6 & -2.3 & 29.8 & & 10.1 & $35.1 !$ & $51.1 !$ & $!$ \\
\hline 11 & 1.2 & 1.5 & 2.5 & 9.9 & -15.2 & 4.7 & & 0.3 & 11.0 & 20.0 & & 2.9 & $34.8 !$ & $41.2 !$ & $!$ \\
\hline 12 & 1.4 & 1.6 & 2.8 & 4.4 & -3.9 & 13.0 & & 8.8 & $39.9 !$ & 6.5 & $!$ & 10.7 & $52.2 !$ & $27.2 !$ & $!$ \\
\hline 13 & 1.5 & 1.5 & 3.6 & 7.3 & 1.8 & 14.9 & & 20.9 & 26.8 & 23.9 & & 16.6 & $35.1 !$ & $54.5 !$ & $!$ \\
\hline 14 & 1.1 & 1.6 & 3.0 & -2.6 & 5.1 & 0.0 & & 8.6 & -1.1 & 28.7 & & 4.4 & $32.0 !$ & $49.5 !$ & $!$ \\
\hline 15 & & & 2.9 & & & 11.2 & & & & 31.6 & & & & $60.2 !$ & $!$ \\
\hline 16 & 3.2 & 1.8 & & -32.0 & 19.3 & & & 28.4 & $35.5 !$ & & $!$ & -11.5 & $42.1 !$ & & $!$ \\
\hline 17 & 1.1 & 1.4 & 3.0 & -11.8 & -1.9 & -17.5 & & -3.8 & -1.9 & 21.3 & & -3.8 & 22.4 & $38.8 !$ & $!$ \\
\hline 18 & 1.1 & 1.5 & 2.5 & -17.8 & 7.9 & -9.3 & & 7.6 & 11.6 & 30.9 & & -11.2 & $48.8 !$ & $47.6 !$ & $!$ \\
\hline Mean & 1.4 & 1.6 & 3.2 & -2.9 & 0.8 & 7.0 & & 10.5 & 19.7 & 24.2 & & 4.0 & 35.7 & 49.8 & \\
\hline SD & 0.5 & 0.1 & 0.7 & 13.3 & 8.8 & 12.4 & & 10.7 & 15.3 & 12.8 & & 10.2 & 11.3 & 11.5 & \\
\hline \multicolumn{4}{|c|}{ No. of responders } & 0 & 0 & 1 & 1 & 1 & 5 & 2 & 6 & 0 & 14 & 16 & 18 \\
\hline \multicolumn{4}{|c|}{ Percent responders } & 0 & 0 & 6 & 6 & 6 & 29 & 13 & 33 & 0 & 82 & 100 & 100 \\
\hline \multicolumn{16}{|l|}{ Cohort II } \\
\hline 1 & 1.8 & 2.5 & & -0.7 & -0.1 & & & 0.3 & 15.9 & & & -7.6 & $45.6 !$ & & $!$ \\
\hline 2 & 2.0 & 2.4 & 1.4 & -8.0 & -11.4 & -7.3 & & 9.3 & 9.8 & 12.5 & & 13.5 & $45.6 !$ & $42.6 !$ & $!$ \\
\hline 4 & 2.1 & 2.6 & 1.4 & 6.7 & -2.4 & 0.4 & & 11.7 & $33.6 !$ & $24.4 !$ & $!$ & 15.6 & $47.6 !$ & $50.2 !$ & $!$ \\
\hline 5 & 1.8 & 2.0 & 1.5 & -14.9 & -0.1 & 1.0 & & 11.5 & $45.0 !$ & 9.0 & $!$ & 2.3 & $43.2 !$ & $58.7 !$ & $!$ \\
\hline 6 & 2.0 & 2.3 & 1.7 & -3.0 & 3.5 & -1.6 & & 14.0 & 17.9 & 13.0 & & 11.1 & $43.3 !$ & $49.0 !$ & $!$ \\
\hline 8 & 1.7 & 2.2 & 1.6 & -7.6 & -18.3 & -4.1 & & -4.0 & 14.8 & $40.6 !$ & $!$ & 2.7 & $35.0 !$ & $52.2 !$ & $!$ \\
\hline 9 & 1.6 & 2.2 & 1.6 & 9.2 & -5.7 & 4.8 & & -11.5 & $38.2 !$ & $25.6 !$ & $!$ & 0.9 & $46.7 !$ & $60.6 !$ & $!$ \\
\hline 10 & 1.6 & 2.0 & 1.6 & -19.9 & -10.7 & $20.9 !$ & $!$ & -10.3 & $34.2 !$ & $36.6 !$ & $!$ & -12.2 & $46.9 !$ & $40.9 !$ & $!$ \\
\hline 11 & 1.8 & 2.8 & 1.5 & -19.9 & 4.1 & 1.6 & & 4.9 & $34.0 !$ & 15.7 & $!$ & 4.4 & $45.8 !$ & $56.0 !$ & $!$ \\
\hline 12 & 1.9 & 2.3 & 1.9 & -4.2 & 7.7 & 7.5 & & 11.6 & 21.5 & $43.0 !$ & $!$ & -2.8 & $37.4 !$ & $68.1 !$ & $!$ \\
\hline Mean & 1.8 & 2.3 & 1.6 & -6.2 & -3.3 & 2.6 & & 3.8 & 26.5 & 24.5 & & 2.8 & 43.7 & 53.1 & \\
\hline SD & 0.2 & 0.3 & 0.2 & 10.0 & 8.1 & 8.2 & & 9.6 & 11.9 & 13.0 & & 8.9 & 4.2 & 8.7 & \\
\hline \multicolumn{4}{|c|}{ No. of responders } & 0 & 0 & 1 & 1 & 0 & 5 & 5 & 7 & 0 & 10 & 9 & 10 \\
\hline Percent $\mathbf{r}$ & sonders & & & 0 & 0 & 11 & 11 & 0 & 50 & 56 & 70 & 0 & 100 & 100 & 100 \\
\hline Cohort II & & & & & & & & & & & & & & & \\
\hline 1 & 1.5 & 1.6 & ND & 0.8 & 4.1 & ND & & 18.4 & 16.9 & ND & & 7.0 & $48.3 !$ & ND & $!$ \\
\hline 4 & 1.2 & 1.9 & ND & -19.7 & 12.6 & ND & & -5.8 & $30.3 !$ & ND & $!$ & 5.6 & $51.6 !$ & ND & $!$ \\
\hline 5 & 1.2 & 1.6 & ND & -14.2 & -5.7 & ND & & 5.4 & 17.1 & ND & & 6.8 & $48.1 !$ & ND & $!$ \\
\hline 6 & 1.0 & 1.7 & ND & -15.1 & -17.8 & ND & & 5.4 & $33.0 !$ & ND & $!$ & 1.0 & $51.2 !$ & ND & $!$ \\
\hline 8 & 1.7 & 1.6 & ND & -9.3 & -4.5 & ND & & 6.4 & $24.7 !$ & ND & $!$ & 6.6 & $47.3 !$ & ND & $!$ \\
\hline 9 & 1.2 & 1.8 & ND & $36.2 !$ & -3.3 & ND & & 10.3 & $27.9 !$ & ND & $!$ & 4.4 & $62.3 !$ & ND & $!$ \\
\hline 10 & 1.1 & 1.6 & ND & -3.6 & 6.7 & ND & & 9.0 & $32.9 !$ & ND & $!$ & 10.9 & $47.9 !$ & ND & $!$ \\
\hline 12 & 1.3 & 1.5 & ND & -3.2 & 16.5 & ND & & 16.1 & 22.6 & ND & & 8.8 & $52.2 !$ & ND & $!$ \\
\hline Mean & 1.3 & 1.7 & & -3.5 & 1.1 & & & 8.2 & 25.7 & & & 6.4 & 51.1 & & \\
\hline SD & 0.2 & 0.1 & & 17.5 & 11.1 & & & 7.4 & 6.5 & & & 2.9 & 4.9 & & \\
\hline
\end{tabular}




\begin{tabular}{|c|c|c|c|c|c|c|c|c|c|c|c|c|}
\hline \multicolumn{13}{|c|}{ Contents of cultures } \\
\hline & \multicolumn{12}{|c|}{ S. typhi plus: } \\
\hline & \multicolumn{4}{|l|}{ Plasma } & \multicolumn{4}{|c|}{ MN cells } & \multicolumn{4}{|c|}{ MN cells + plasma } \\
\hline & -1 & 22 & 61 & $\mathbf{R}^{\prime \prime}$ & -1 & 22 & 61 & $\mathbf{R}$ & -1 & 22 & 61 & $\mathbf{R}$ \\
\hline No. of responders & 1 & 0 & & 0 & 0 & 5 & & 5 & 0 & 8 & & 8 \\
\hline Percent responders & 13 & 0 & & 0 & 0 & 63 & & 63 & 0 & 100 & & 100 \\
\hline \multicolumn{13}{|l|}{ For all cohorts } \\
\hline $\begin{array}{l}\text { No. of responder } \\
\text { of vaccinees }\end{array}$ & $1 / 35$ & $0 / 35$ & $2 / 25$ & $2 / 35$ & $1 / 35$ & $15 / 35$ & $7 / 24$ & $18 / 35$ & $0 / 35$ & $32 / 35$ & $25 / 25$ & $36 / 36$ \\
\hline$\%$ responders & 3 & 0 & 8 & 6 & 3 & 43 & 29 & 51 & 0 & 91 & 100 & 100 \\
\hline
\end{tabular}

ND, not done. * The number of vaccinees tested differs from the total number of volunteers because of failure to obtain some postvaccination samples and occasional technical problems with individual assays. ${ }^{\ddagger}$ Interval in days in relation to vaccination. "Individuals in cohort III were evaluated at day 93 after vaccination. "Responders (see below) on either day 22 or 61 postvaccination. 'Mean number of colony-forming units $\times 10,000$ for triplicate cultures. ** Percent of control cultures calculated as: $100-(100)($ mean CFU of experimental tubes/mean CFU of control tubes). \#! denotes responders, defined as those individuals whose average percent of control value exceeded by 2 SD the prevaccination mean for the cohort.

the attenuated $S$. typhi strains used heretofore in humans is that these strains elicit protective immunity without causing notable adverse reactions $(9-12,36,37)$, in stark contrast to the highly reactogenic parenteral killed whole-cell vaccines.

The widely used galE mutant attenuated $S$. typhi vaccine strain, Ty $21 \mathrm{a}$, is empirically safe and protective (9-21). Nevertheless, it suffers from several theoretical drawbacks, most notable of which are the lack of knowledge of the genetic lesions responsible for changes in the activity of Leloir pathway enzymes and the inadvertent occurrences of other phenotypic changes consequent to the nonspecific method of mutagenesis employed to derive the vaccine strain. The perception of these drawbacks in Ty21a stems from the general progress in vaccine development biotechnology that has occurred since the galE mutants were prepared in the early 1970 s. The suggestion that these deficiencies exist in no way diminishes recognition for the pathfinder role that Ty21a has played in demonstrating the superiority and advantages of live oral typhoid vaccines over parenteral killed vaccines (12).

In the 1980s, modern methods of genetic manipulation have been applied to develop attenuated $S$. typhi mutants with known and precise attenuating genetic lesions $(13,14)$. The first candidate strains to be created in this manner are the Aro-, Pur-, auxotrophic mutants, 541Ty and 543Ty, of Stocker and coworkers in ongoing work. Accordingly, studies were undertaken in man with these two auxotrophic mutants of $S$. typhi to assess their infectivity, safety, and immunogenicity. The genetic lesions responsible for attenuation in these vaccine strains are deletions in specific genes causing nutritional requirements and not affecting other portions of the genome. As reported herein, these Aro-, Pur- strains elicited no notable adverse reactions among 37 young adults, even when given with buffer in doses as high as $2 \times 10^{10}$ organisms (Table I). These doses are an impressive measure of the innocuity of the vaccines, since with wild $S$. typhi $10^{5}$ organisms cause typhoid fever in $\sim 50 \%$ of recipients and $10^{9}$ lead to illness in $90 \%-100 \%$ of individuals $(9,36,37,42)$.

Vaccine organisms were recovered from 30 to 37 vaccinees, mostly in stool cultures ( 29 of 37 ). The number of positive cul- tures and the geometric mean titer of organisms per gram of stool were maximum within the first $48 \mathrm{~h}$ after vaccination, greatly diminishing thereafter; no positive cultures occurred beyond $96 \mathrm{~h}$ after ingestion of vaccine. It is believed that attenuated $S$. typhi vaccine strains such as $541 \mathrm{Ty}, 543 \mathrm{Ty}$, and Ty21 a rapidly translocate from the intestinal lumen to the mesenteric lymph nodes from which they enter the lymphatic circulation, thoracic duct, and blood circulation, and finally reach the reticuloendothelial system where they are ingested by fixed macrophages $(43,44)$. In these steps the attenuated Salmonella resemble the pathogenesis of infection with pathogenic $S$. typhi or $S$. typhimurium (in animals). However, whereas pathogenic $S$. typhi and $S$. typhimurium survive and proliferate within the macrophages of the reticuloendothelial system for many weeks, attenuated Salmonella, which are impaired in their ability to proliferate and survive, remain viable within the macrophages for much shorter periods $(31,35)$. Ideally, the period of intracellular survival is sufficiently long to stimulate immunity $(35,38,40,41$, $44,45)$, particularly cell-mediated responses $(38,40,44,45)$, but not long enough to lead to clinical illness. Studies with Aro$S$. typhimurium vaccine in calves (44), and with a galE mutant of $S$. typhimurium in mice (31), have documented these events by autopsy of animals at varying intervals after vaccination and by examining organs of the reticuloendothelial system histologically and bacteriologically. It is presumed that these events also occur in humans after ingestion of attenuated $S$. typhi strains 541Ty, 543Ty, and Ty21a but this is extremely difficult to document. Repeated blood cultures after vaccination of volunteers with Aro-S. typhi in this study or with Ty21a in previous studies (12) failed to recover $S$. typhi. This does not exclude that a silent primary bacteremia occurred; rather it implies a very short bacteremia with few organisms and draws attention to the limitations of our sampling methods to detect the event. Even in full-blown typhoid fever, the concentration of bacteria in blood is very low, circa $10^{1}$ organisms per milliliter (46-48). Thus, it is probable that we simply failed with our blood culture techniques to detect the event. Aspiration and culture of bone marrow 1-3 d after ingestion of vaccine should provide greater sensitivity to dem- 
onstrate the dissemination of the vaccine organisms to the organs of the reticuloendothelial system (49-55). However, for ethical reasons this was considered too invasive a procedure to incorporate in this phase 1 vaccine evaluation.

During the primary bacteremia that occurs with pathogenic (and presumably also with attenuated) Salmonella, the organisms also reach the gall bladder (49-55) where they persist during the acute infection; in 2\%-5\% of typhoid fever patients (usually those with previous gall bladder pathology) a chronic carrier state ensues (56-59). Isolation of $S$. typhi from the bile by means of bile-stained duodenal string cultures is a sensitive method to recover the organism from suspect cases of typhoid fever, thereby confirming the diagnosis $(20,60-64)$. As shown in Table II, the attenuated vaccine strain was recovered from duodenal string cultures of two recipients of higher doses of strain 541Ty. One possible explanation for these positive cultures is that the attenuated Salmonella temporarily colonized the proximal small intestine. In view of the potency of the peristaltic defense mechanism (43), this is considered unlikely. Rather, these isolations more probably represent the arrival of the vaccine organisms in the gall bladder after dissemination.

The humoral antibody response to $S$. typhi $\mathrm{O}, \mathrm{H}$, and lysate antigens in recipients of the Aro- strains was quite meager (Table III), nor did either vaccine stimulate Vi antibodies. In general, the serologic response of North Americans after ingestion of earlier attenuated $S$. typhi vaccines, including streptomycin-dependent and galE mutants, was also relatively meager $(9,36$, $37,65)$. It is difficult to compare the serologic response in recipients of Aro- strains with individuals who received Ty21a or streptomycin-dependent vaccines because of differences in formulation, dosage, and the tests used to monitor the serologic response.

Most data support the concept that the critical immunity elicited by live oral Salmonella vaccines is cell-mediated (31$35,38,40,41,44,45,66-69)$. Until recently, the antigens responsible for the specificity of the cellular immune response against Salmonella were not known. Studies in volunteers with Ty21a demonstrated that a smooth lipopolysaccharide $\mathrm{O}$ antigen was necessary in order for Ty21a to be immunogenic and protective (9). Lindberg and co-workers $(27,28,35,44)$ working with both pathogenic and attenuated Aro- $S$. typhimurium demonstrated, by means of lymphocyte stimulation assays and delayed hypersensitivity skin tests, that a specific cellular immune response was directed toward the $O$ polysaccharide. Based on these observations in animals, we utilized various $O$ polysaccharides, in addition to killed bacteria, as antigens in lymphocyte replication assays. $O$ polysaccharides were cleaved from lipid $A$ and core sugars to provide highly specific antigens free from nonspecific mitogenic activity. The lymphocyte replication assays with killed whole bacteria demonstrated an immune response in most vaccinees which was shown to be highly specific for $S$. typhi (Table V); bacterial cells of other Enterobacteriaceae, including closely related $S$. enteritidis, did not stimulate the lymphocytes collected postvaccination. Stimulation studies with the $O$ polysaccharides demonstrated that a major component of the cellular immune response was directed at the $O$ antigen component of the LPS. The specificity of the cellular immune response involving the $O$ polysaccharides was quite astonishing (Table VI). Heretofore, it had been accepted that the $O$ antigens of $S$. typhi and $S$. enteritidis bioserotype enteriditis were identical $(19,70)$. LPS prepared from these two Salmonella are virtually interchangeable when used as antigens in ELISA (26), demon- strating considerable immunologic relatedness. Yet in the lymphocyte replication assays, the postvaccination lymphocytes clearly differentiated $S$. typhi from $S$. enteritidis, whether whole bacteria or purified $O$ polysaccharide were used. This implies that while common epitopes exist on these two $O$ polysaccharides that bind antibodies in ELISA, there also exist epitopes within the $S$. typhi $\mathrm{O}$ polysaccharide which are specific for $S$. typhi. It is conceivable that, in addition to immunity focussed against the $O$ polysaccharides, there may also be an immune response directed at (as yet uncharacterized) protein antigens on the bacterial surface (71).

Recognition of the importance of the $O$ antigen was the major reason for development of strain 543Ty, the Vi-negative variant of 541Ty. Vi polysaccharide is a linear homopolymer of alpha $1 \rightarrow 4,2$ deoxy-2- $N$-acetylgalacturonic acid forming a capsule that covers the $\mathrm{O}$ antigen of $S$. typhi $(72,73)$. It was not known if the presence of $\mathrm{Vi}$ on 541Ty might dampen the immune response to the $\mathrm{O}$ antigen; for this reason the Aro-, Pur- variants with and without Vi were tested in parallel. There was no evidence that the immune response to 541Ty was in any way diminished in comparison with 543Ty. Nor was there any evidence of a serologic response to $\mathrm{Vi}$ in recipients of either strain. Although $\mathrm{Vi}$ is a recognized virulence property of $S$. typhi (73), only approximately one-third of patients with acute typhoid fever manifest detectable antibody titers of Vi antibody (26). In contrast, $\sim 80 \%$ of chronic $S$. typhi carriers have very elevated titers of $\mathrm{Vi}$ antibody (26), making this an excellent screening test for the carrier state even in endemic areas if highly purified Vi is used as antigen in the serologic test (26). Very potent immunity can occur in the absence of Vi. For example, Ty21a lacks Vi (8, 9) yet provides significant protection against typhoid fever due to Vi-positive strains of $S$. typhi.

The most sensitive assay to measure immune response to the Aro-, Pur - vaccine strains involved studies of the inhibition of $S$. typhi in vitro using mononuclear cells, plasma, or both in combination. It was found that, although postvaccination mononuclear cells by themselves exhibited inhibitory activity against $S$. typhi, the addition of postvaccination plasma significantly enhanced the inhibition (Table VII); in contrast, plasma by itself had virtually no inhibitory activity. These results parallel similar findings by Italian investigators (45) showing the development of antibody-dependent cell-mediated inhibition of pathogenic $S$. typhi in persons vaccinated with Ty21a. These investigators show preliminary evidence that $\mathrm{T}$ lymphocytes are critical cells involved in the inhibition of the Salmonella and that IgA antibody may also be involved (45). Although considerable work has yet to be carried out to investigate the operative components in plasma, the cell types and products involved and the precise effect on the Salmonella, the "growth inhibition" assays of Tagliabue et al. (45) and ourselves have proved to be extremely useful in measuring immune responses to oral attenuated $S$. typhi vaccines.

Aro-, Pur-auxotrophic mutants of $S$. typhi used as live oral vaccines in these initial phase 1 studies in humans have been found to be safe, infective, and immunogenic, particularly in stimulating cell-mediated immunity. Because no evidence was found to suggest that the presence of the Vi polysaccharide diminishes immunogenicity, further trials will proceed with strain $541 \mathrm{Ty}$. Stimulated by the highly encouraging results reported herein, expanded phase 2 clinical trials will be carried out in outpatient volunteers with vaccine strain 541 Ty to evaluate immune response after variations in dosage, immunization sched- 
ules, and formulations. It is anticipated that these further studies will prepare the way for a definitive field trial of vaccine efficacy.

\section{Acknowledgments}

These studies were supported by research contract no. 1 AI-12666 (to Dr. Levine) from the National Institute of Allergy and Infectious Diseases and by grants from the World Health Organization (to Dr. Levine), Praxis Biologics, Inc., Rochester, NY (to Dr. Levine), and the Swedish Medical Research Council (no. 16x-656 to A. A. Lindberg). The work of Drs. Edwards and Stocker was supported by Public Health Service research grants AI-07168 and AI-18872 from the National Institute of Allergy and Infectious Diseases, research contracts from the U.S. Army Medical Research and Development Command and Smith Kline-RIT, and by gifts from Praxis Biologics, Inc., and Johnson \& Johnson.

\section{References}

1. Edelman, R. E., and M. M. Levine. 1986. Summary of an international workshop on typhoid fever. Rev. Infect. Dis. 8:329-349.

2. Ashcroft, M. T., J. Morrison-Ritchie, and C. C. Nicholson. 1964. Controlled field trial in British Guiana schoolchildren of heat-killed phenolized and acetone-killed lyophilized typhoid vaccines. Am. J. Hyg. 79:196-206.

3. Cvjetanovic, B., and K. Uemura. 1965. The present status of field and laboratory studies of typhoid and paratyphoid vaccines. Bull. WHO. 32:29-36.

4. Polish Typhoid Committee. 1965. Evaluation of typhoid vaccines in the laboratory and in a controlled field trial in Poland. Bull. WHO. 32:15-27.

5. Tapa, S., and B. Cvjetanovic. 1972. Controlled field trial on the effectiveness of one and two doses of acetone-inactivated and dried typhoid vaccine. Bull. WHO. 52:75-80.

6. Yugoslav Typhoid Commission. 1964. A controlled field trial of the effectiveness of acetone-dried and inactivated and heat-phenol-inactivated typhoid vaccines in Yugoslavia. Bull. WHO. 30:623-630.

7. Ashcroft, M. T., B. Singh, C. C. Nicholson, J. M. Ritchie, E. Sobryan, and F. Williams. 1967. A seven year field trial of two typhoid vaccines in Guyana. Lancet. ii:1056-1059.

8. Germanier, R., and E. Furer. 1975. Isolation and characterization of gal E mutant Ty21a of Salmonella typhi: a candidate strain for a live oral typhoid vaccine. J. Infect. Dis. 131:553-558.

9. Gilman, R. H., R. B. Hornick, W. E. Woodward, H. L. DuPont, M. J. Snyder, M. M. Levine, and J. P. Libonati. 1977. Immunity in typhoid fever: evaluation of Ty2 1a -an epimeraseless mutant of S. typhi as a live oral vaccine. J. Infect. Dis. 136:717-723.

10. Wahdan, M. H., C. Serie, Y. Cerisier, S. Sallam, and R. Germanier. 1982. A controlled field trial of live Salmonella typhi strain Ty21a oral vaccine against typhoid: three year results. J. Infect. Dis. 145:292-296.

11. Levine, M. M., R. E. Black, C. Ferreccio, M. L. Clements, C. Lanata, J. Rooney, R. Germanier, and Chilean Typhoid Committee. 1987. Field trials of efficacy of attenuated Salmonella typhi oral vaccine strain Ty21a. In Proceedings of the International Symposium on Bacterial Vaccines. J. Robbins, editor, Praeger Publishers, New York. In press.

12. Levine M. M., R. E. Black, C. Ferreccio, M. L. Clements, C. Lanata, J. Rooney, and Chilean Typhoid Committee. 1986. The efficacy of attenuated Salmonella typhi oral vaccine strain Ty21a evaluated in controlled field trials. In Proceedings of the Nobel Conference on Recent Advances in Vaccines and Drugs against Diarrhoeal Diseases, Stockholm, 3-6 June 1985. J. Holmgren, A. Lindberg, and R. Mollby, editors. Student Literatur, Gothenburg, Sweden. 90-100.

13. Stocker, B. A. D., S. K. Hoiseth, and B. P. Smith. 1983. Aromaticdependent Salmonella sp. as a live vaccine in mice and calves. Dev. Biol. Stand. 53:47-54.

14. Edwards, M. F. 1985. Auxotrophic Salmonella typhi as live vaccines and the $f+$ plasmid of $S$. typhimurium: two studies on Salmonella virulence. Ph.D. dissertation. Stanford University School of Medicine, Stanford, CA.

15. Hoiseth, S., and B. A. D. Stocker. 1981. Aromatic-dependent Salmonella typhimurium are non-virulent and effective as live vaccines. Nature (Lond.). 291:238-239.

16. Bacon, G. A., T. W. Burrows, and M. Yates. 1951. The effects of biochemical mutation on the virulence of Bacterium typhosum: the loss of virulence of certain mutants. Br. J. Exp. Pathol. 32:85-96.

17. Levine, M. M., E. J. Bergquist, D. R. Nalin, D. H. Waterman, R. B. Hornick, C. R. Young, S. Sotman, and B. Rowe. 1978. Escherichia coli strains that cause diarrhoeal but do not produce heat-labile or heatstable enterotoxins and are non-invasive. Lancet. i:1119-1122.

18. Martin, W. J., and J. A. Washington. 1980. Enterobacteriaceae. In Manual of Clinical Microbiology. E. H. Lennette, A. Balows, W. J. Hausler, Jr., and J. P. Truant, editors. American Society for Microbiology, Washington, DC. 195-219.

19. Edwards, P. R., and W. H. Ewing. 1972. Identification of Enterobacteriaciae. 3rd edition. Burgess Publishing Co., Minneapolis. 362 pp.

20. Avendano, A., P. Herrera, I. Horwitz, E. Duarte, I. Prenzel, C. Lanata, and M. M. Levine. 1986. Duodenal string cultures: practicality and sensitivity for diagnosing enteric fever in children. J. Infect. Dis. 153:359-362.

21. Young, C. R., M. M. Levine, J. P. Craig, and R. Robins-Browne. 1980. Microtiter enzyme-linked immunosorbent assay (ELISA) for IgG cholera antitoxin in man. I. Method and correlation with rabbit skin vascular permeability factor technique. Infect. Immun. 27:492-496.

22. Levine, M. M., R. E. Black, M. L. Clements, C. Lanata, S. Sears, T. Honda, C. R. Young, and R. A. Finkelstein. 1984. Evaluation in man of attenuated Vibrio cholerae El Tor Ogawa strain Texas Star-SR as a live oral vaccine. Infect. Immun. 43:515-522.

23. Carlsson, H. E., A. A. Lindberg, and S. Hammarstrom. 1972. Titration of antibodies to Salmonella $\mathrm{O}$ antigens by enzyme-linked immunosorbent assay. Infect. Immun. 6:703-708.

24. Levine, M. M., O. Grados, R. H. Gilman, W. E. Woodward, R. Solis-Plaza, and W. Waldman. 1978. Diagnostic value of the Widal test in areas endemic for typhoid fever. Am. J. Trop. Med. Hyg. 27:795800.

25. Lanata, C. F., M. M. Levine, C. Ristori, R. E. Black, L. Jimenez, M. Salcedo, J. Garcia, and V. Sotomayor. 1983. Vi serology in detection of chronic Salmonella typhi carriers in an endemic area. Lancet. ii:441443.

26. Tacket, C. O., C. Ferreccio, J. B. Robins, C.-M. Tsai, D. Schulz, M. Cadoz, A. Goudeau, and M. M. Levine. 1986. Safety and characterization of the immune response to two Salmonella typhi Vi capsular polysaccharide vaccine candidates. J. Infect. Dis. 154:342-345.

27. Robertsson, J. A., S. B. Svenson, and A. A. Lindberg. 1982. Salmonella typhimurium infection in calves: delayed specific skin reactions directed against the $\mathrm{O}$-antigenic polysaccharide chain. Infect. Immun. 37:737-748.

28. Robertsson, J. A., C. Fossum, S. Svenson, and A. A. Lindberg. 1982. Salmonella typhimurium infection in calves: specific immune reactivity against $\mathrm{O}$-antigenic polysaccharide detectable in in vitro assays. Infect. Immun. 37:728-736.

29. Levine, M. M., J. B. Kaper, H. Lockman, R. E. Black, and M. L. Clements. 1983. Recombinant DNA risk assessment studies in man: efficacy of poorly mobilizable plasmids in biologic containment. J. Infect. Dis. 148:699-709.

30. Nencioni, L., L. Villa, D. Boraschi, B. Berti, and A. Tagliabue. 1983. Natural and antibody-dependent cell-mediated activity against Salmonella typhimurium by peripheral and intestinal lymphoid cells in mice. J. Immunol. 130:903-907.

31. Germanier, R. 1970. Immunity in experimental salmonellosis. I. Protection induced by rough mutants of Salmonella typhimurium. Infect. Immun. 2:309-315.

32. Germanier, R., and E. Furer. 1971. Immunity in experimental salmonellosis. II. Basis for the avirulence and protective capacity of gal E mutant of Salmonella typhimurium. Infect. Immun. 4:663-673.

33. Germanier, R. 1972. Immunity in experimental Salmonellosis. 
III. Comparative immunization with viable and heat-inactivated cells of Salmonella typhimurium. Infect. Immun. 5:792-797.

34. Collins, F. M., and P. B. Carter. 1972. Comparative immunogenicity of heat-killed and living oral Salmonella vaccines. Infect. Immun. 6:451-458.

35. Robertsson, J. A., A. A. Lindberg, S. Hoiseth, and B. A. D. Stocker. 1983. Salmonella typhimurium infection in calves: protection and survival of virulent challenge bacteria after immunization with live or inactivated vaccines. Infect. Immun. 41:742-750.

36. DuPont, H. L., R. B. Hornick, M. J. Snyder, J. P. Libonati, and T. E. Woodward. 1970. Immunity in typhoid fever: evaluation of live streptomycin-dependent vaccine. Antimicrob. Agents Chemother. 1971: 236-239.

37. Levine, M. M., H. L. DuPont, R. B. Hornick, M. J. Snyder, W. E. Woodward, R. H. Gilman, and J. P. Libonati. 1976. Attenuated streptomycin-dependent Salmonella typhi oral vaccine: potential deleterious effects of lyophilization. J. Infect. Dis. 133:424-429.

38. Eisenstein, T. K., L. M. Killar, B. A. D. Stocker, and B. M. Sultzer. 1984. Cellular immunity induced by avirulent Salmonella in LPS-defective C3H/HeJ mice. J. Immunol. 133:958-961.

39. Eisenstein, T. K., and C. R. Angerman. 1978. Immunity to experimental Salmonella infection: studies on the protective capacity and immunogenicity of lipopolysaccharide, acetone-killed cells, and ribosomerich extracts of Salmonella typhimurium in $\mathrm{C} 3 \mathrm{H} / \mathrm{HeJ}$ and $\mathrm{CD}-1$ mice. J. Immunol. 121:1010.

40. Killar, L. M., and T. K. Eisenstein. 1984. Differences in delayedtype hypersensitivity responses in various mouse strains in the $\mathrm{C} 3 \mathrm{H}$ lineage infected with Salmonella typhimurium, strain SL3235. J. Immunol. 133:1190-1196.

41. Killar, L. M., and T. K. Eisenstein. 1985. Immunity to Salmonella typhimurium infection in $\mathrm{C} 3 \mathrm{H} / \mathrm{HeJ}$ and $\mathrm{C} 3 \mathrm{H} / \mathrm{NeNCr} / \mathrm{Br}$ mice: studies with an aromatic-dependent live $S$. typhimurium strain as a vaccine. Infect. Immun. 47:605-612.

42. Hornick, R. B., S. E. Greisman, T. E. Woodward, H. L. DuPont, A. T. Dawkins, and M. J. Snyder. 1970. Typhoid fever: pathogenesis and immunologic control. N. Engl. J. Med. 283:686-691; 739-746.

43. Levine, M. M., J. B. Kaper, R. E. Black, and M. L. Clements. 1983. New knowledge on pathogenesis of bacterial enteric infections as applied to vaccine development. Microbiol. Rev. 47:510-550.

44. Lindberg, A. A., and J. A. Robertsson. 1983. Salmonella typhimurium infection in calves: cell-mediated and humoral immune reactions before and after challenge with live virulent bacteria in calves given live or inactivated vaccine. Infect. Immun. 41:751-757.

45. Tagliabue, A., L. Nencioni, A. Caffarena, L. Villa, D. Boraschi, G. Cazzola, and S. Cavalieri. 1985. Cellular immunity against Salmonella typhi after live oral vaccine. Clin. Exp. Immunol. 62:242-247.

46. Watson, K. C. 1955. Isolation of Salmonella typhi from the blood stream. J. Lab. Clin. Med. 46:128-134.

47. Kaye, D., M. Palmier, L. Eyckmans, H. Rocha, and E. W. Hook. 1966. Comparison of bile and trypticase soy broth for isolation of Salmonella from blood. Am. J. Clin. Pathol. 36:408-410.

48. Watson, K. C. 1975. Laboratory diagnosis of typhoid fever. Lancet. i:1377.

49. Ling, C.-C., S. S. Taur, P. C. Hsueh, and S. Y. Yang. 1940. Medulloculture in the diagnosis of typhoid and paratyphoid fevers in an analysis of 38 cases. Chin. Med. J. 57:11-26.

50. Piaggio Blanco, R. A., P. Paseyro, and C. M. Sanguinetti. 1942. El medulocultivo como metodo de diagnostico en la fiebre tifoidea. Arch. Urug. Med. Cir. Espec. 20:413-423.

51. Schlack, L., M. Pino, and A. Wiederhold. 1966. El mielocultivo en el diagnostico de fiebre tifoidea y paratifoidea. Analisis comparativo de 135 casos a su ingreso hospitalario. Rev. Chil. Pediatr. 37:213-220.

52. Gilman, R. H., M. Terminel, M. M. Levine, P. Hernandez-Mendoze, and R. B. Hornick. 1975. Relative efficacy of blood, urine, rectal swab, bone-marrow, and rose-spot cultures for recovery of Salmonella typhi in typhoid fever. Lancet. i:1211-1213.
53. Guerra-Caceras, J. G., E. Gotuzzo-Herencia, E. Crosby-Dagnino, M. Miro-Quesada, and C. Carrillo-Parodi. 1979. Diagnostic value of bone marrow culture in typhoid fever. Trans. Rev. Soc. Trop. Med. Hyg. 73:680-683.

54. Chang, J. E., H. Hernandez, A. Yi, E. Chea, E. Chaparro, E. Matos, and A. Pina. 1982. Hemocultivo y mielocultivo en ninos con fiebre tifoidea. Bol. Med. Hosp. Infant. Mex. 39:614-616.

55. Hoffman, S. L., N. H. Punjabi, R. C. Rockhill, A. Sutomo, A. R. Rivai, and S. P. Pulungsih. 1984. Duodenal string-capsule culture compared with bone-marrow, blood and rectal swab cultures for diagnosing typhoid and paratyphoid fever. J. Infect. Dis. 149:157-161.

56. Stokes, A., and C. Clarke. 1916. A search for typhoid carriers among 800 convalescents. Lancet. i:566-569.

57. Ledingham, J. C. G., and J. A. Arkwright. 1912. The carrier problem in infectious diseases. Edward Arnold, London. 5-135.

58. Armijo, R., A. Pizzi, and H. Lobos. 1967. Prevalencia de portadores tificos despues del tratamiento con cloranfenicol. Biol. Sanit. Panam. 62:295-302.

59. Ames, W. R., and M. Robins. 1943. Age and sex as factors in the development of the typhoid carrier state, and a model for estimating carrier prevalence. Am. J. Public Health. 33:221-230.

60. Gilman, R. H., and R. B. Hornick. 1976. Duodenal isolation of Salmonella typhi by string capsule in acute typhoid fever. J. Clin. Microbiol. 3:456-457.

61. Benavente, L., E. Gotuzzo, J. Guerra, O. Grados, and H. Guerra. 1981. Diagnosis of Salmonella typhi by culture of duodenal string capsule. N. Engl. J. Med. 304:54.

62. Benavente, L., E. Gotuzzo, J. Guerra, O. Grados, H. Guerra, and N. Bravo. 1984. Diagnosis of typhoid fever using a strong capsule device. Trans. Rev. Soc. Trop. Med. Hyg. 78:404-406.

63. Vallenas, C., H. Hernandez, B. Day, R. Black, and E. Gotuzzo. 1985. Efficacy of bone marrow, blood, stool and duodenal contents cultures for bacteriologic confirmation of typhoid fever in children. Pediatr. Infect. Dis. 4:496-498.

64. Medina, E., and M. Yrarrazaval. 1983. Fiebre tifoidea en Chile: consideraciones epidemiologicas. Rev. Med. Chil. 111:609-615.

65. Black, R. E., M. M. Levine, C. R. Young, J. Rooney, S. Levine, M. L. Clements, S. O'Donnell, T. P. Hughes, Chilean Typhoid Committee, and R. Germanier. 1983. Immunogenicity of Ty21a attenuated Salmonella typhi given with sodium bicarbonate or in enteric-coated capsules. Dev. Biol. Stand. 53:9-14.

66. Smith, R. A., A. Esa, and M. Stiff. 1983. Transfer of Salmonella resistance and delayed hypersensitivity with murine-derived transfer factor. Infect. Immun. 36:271-276.

67. Mackaness, G. B., R. V. Blanden, and F. M. Collins. 1966. Hostparasite relations in mouse typhoid. J. Exp. Med. 124:573-583.

68. Blanden, R. V., G. B. Mackaness, and F. M. Collins. 1966. Mechanisms of acquired resistance in mouse typhoid. J. Exp. Med. 124: 585-600.

69. Collins, F. M., R. V. Blanden, and G. B. Mackaness. 1966. Infection immunity in experimental salmonellosis. J. Exp. Med. 124:601619.

70. Hellerquist, C. G., B. Lindberg, S. Svenson, T. Holme, and A. A. Lindberg. 1969. Structural studies on the O-specific side chains of the cell wall lipopolysaccharides from Salmonella typhi and $S$. enteritidis. Acta. Chem. Scand. 23:1588-1996.

71. Calderon, I., S. R. Lobos, H. A. Rojas, C. Palomino, L. H. Rodriguez, and G. C. Mora. 1986. Antibodies to porin antigens of Salmonella typhi induced during typhoid infection in humans. Infect. Immun. 52: 209-212.

72. Heyns, K., G. Kiessling, W. Lindenberg, H. Paulsen, and M. E. Webster. 1959. D-galaktosaminuornsäure (2-amino-2-desoxy-D-galakturonsäure) als Baustein des Vi-antigens. Chem. Ber. 92:2435-2437.

73. Robbins, J. D., and J. B. Robbins. 1984. Reexamination of the protective role of the capsular polysaccharide (Vi antigen) of Salmonella typhi. J. Infect. Dis. 150:436-449. 